\title{
Matematik Tarihi Destekli Matematik Derslerine Yönelik Motivasyon Ölçeğinin Geliştirilmesi: Geçerlik ve Güvenirlik Çalışması*
}

\author{
Development of Motivation Scale for the Mathematics Course \\ Supported by History of Mathematics: Validity and Reliability Study*
}

\author{
Nazan MERSIN ${ }^{l}$ \\ Soner DURMUŞS
}

\begin{abstract}
Alıntılama: Mersin, N. \& Durmuş, S. (2020). Matematik tarihi destekli matematik derslerine yönelik motivasyon ölçeğinin geliştirilmesi: Geçerlik ve güvenirlik çalışması. Ulusal Eğitim Akademisi Dergisi (UEAD), 4(2), 110-147.
\end{abstract}

Geliş tarihi:

06 Teтmuz, 2020

Kabul tarihi:

28 A $\breve{g}$ ustos 2020

(C) UEAD 2020

Tüm hakları saklıdır.
Özet: $\mathrm{Bu}$ çalışmanın amacı ortaokul öğrencilerinin matematik tarihi destekli matematik derslerine yönelik motivasyonlarını ölçmek amacıyla bir ölçme aracının geliştirilmesidir. Bu doğrultuda De Vellis'in (2016) ölçek geliştirme süreçleri takip edilmiştir. Öncelikle alanyazındaki ilgili ölçekler incelenmiş ve 99 maddelik taslak ölçek oluşturulmuştur. Kapsam geçerliliği için taslak ölçek 5 alan uzmanı, 3 ölçme değerlendirme uzmanı ve 1 dil uzmanı tarafından incelenmiş ve öneriler doğrultusunda gerekli düzeltmeler yapılmıştır. Oluşturulan taslak ölçek Bolu ilinde farklı iki devlet okulunda yer alan 397 ortaokul öğrencisine uygulanmıştır. Elde edilen veri setine sırasıyla açımlayıcı faktör analizi (AFA) ve doğrulayıcı faktör analizi (DFA) yapılmıștır. AFA sonrasında üç faktör ve otuz dokuz maddeden oluşan bir ölçek elde edilmiştir. Bu faktörler ise sırasıyla matematik tarihi destekli matematik derslerine yönelik içsel motivasyon, dışsal motivasyon ve motivasyon yoksunluğu olarak adlandırılmıştır. DFA sonrasında ise modelin iyi veya kabul edilebilir $(\chi 2 / \mathrm{df}=1.86$, RMSEA $=0.46$, GFI $=0.86$, AGFI $=0.84, \mathrm{CFI}=0.94)$ düzeyde olduğu görülmüștür. Doğrulayıcı faktör analizinin, açımlayıcı faktör analizi ile tutarlı olduğu bu ölçeğin iç güvenirlik katsayıs1, ölçeğin bütünü için .932, içsel motivasyon için .95 , motivasyon yoksunluğu için .96 ve dişsal motivasyon için .78 olarak hesaplanmıştır. Bu değerlerin .70'in üzerinde olması ise ölçeğin yüksek düzeyde güvenilir olduğunu göstermektedir.

\footnotetext{
${ }^{1}$ (Sorumlu yazar)Dr. Arş. Gör., Çanakkale 18 Mart Üniversitesi, nazan09gunduz@gmail.com, ORCID ID:0000-0002-4208-3807.

2 Prof. Dr., Bolu Abant İzzet Baysal Üniversitesi, sonerdurmus@gmail.com, ORCID ID:0000-0003-39781580.

*Bu çalışma birinci yazarın Bolu Abant İzzet Baysal Üniversitesi BAP birimi BAP-2018.02.05.1326 numaralı projesiyle destekli doktora tezinin bir bölümünden oluşmaktadır.
} 
Matematik Tarihi Destekli Matematik Derslerine Yönelik Motivasyon Ölçeğinin

Geliştirilmesi: Geçerlik ve Güvenirlik Çalışması

Received:

O6 July 2020

Accepted:

28 August 2020

(c) UEAD 2020

All rights reserved.
Anahtar kelimeler: Matematik tarihi, matematik dersi, motivasyon, ölçek geliştirme, ortaokul öğrencileri

\begin{abstract}
This study aims to develop an evaluation tool to measure the motivation of middle school students for the mathematics course supported by history of mathematics. In this direction, the scale development procedures of De Vellis (2016) were followed. First of all, the associated scales in the literature were explored, and a 99-item draft scale was formed. The draft scale was examined for scope validity by 5 field experts, 3 assessment and evaluation experts and 1 language expert, so the necessary corrections were implemented according to the suggestions. The draft scale was applied to 397 middle school students in two different public schools in Bolu city. Exploratory factor analysis (EFA) and confirmatory factor analysis (CFA) were applied to the obtained data, respectively. After AFA, a structure consisting of thirty-nine items and three factors was obtained. These factors are called intrinsic motivation, extrinsic motivation and amotivation of the mathematics course supported by HM. After confirmatory factor analysis, the model was found to be fit or acceptable $(\chi 2 / \mathrm{df}=1.86, \mathrm{RMSEA}=0.046, \mathrm{GFI}=0.86, \mathrm{AGFI}=0.84, \mathrm{CFI}=0.94)$. The intrinsic reliability coefficient of this scale, in which the confirmatory factor analysis is consistent with the explanatory factor analysis, was calculated as 0.93 for the entire scale, 0.95 for intrinsic motivation, 0.96 for amotivation and 0.78 for extrinsic motivation. If this value is above 0.70 , it indicates that the scale is highly reliable.
\end{abstract}

Keywords: History of mathematics, mathematics course, motivation, scale development, middle school students.

\section{Giriş}

İnsanlar, var olduğu günden beri matematiğe merak salmışlardır. Matematik başlarda doğayı anlamaya yönelik kullanılırken, insanların ihtiyaçları değiştikçe matematiği kullanma yöntemleri de farklılık göstermiş, tarımdan astronomiye, endüstriden ticarete, bilişimden ekonomiye pek çok alanda kullanılır hale gelmiştir. Bu durumda matematik, insanların hayatlarını devam ettirebilmeleri için neredeyse yaşamlarının vazgeçilmez bir öğesi olmuştur. Dolayısıyla bireylere yaşamlarında ihtiyaçları olan matematiksel bilgileri ve problem çözme, akıl yürütme, iletişim, ilişkilendirme, yaratıcılık gibi becerileri kazandırmak amacıyla matematik bir zorunluluk olarak görülmektedir (Deringöl, 2018). Bu sebeple ülkemizde okul öncesinden itibaren öğrencilere matematiksel yeterlikler kazandırılmaya çalışılmaktadır (MEB, 2013). Ancak matematik, eğitimin ilk yıllarından itibaren birçok öğrenci için korku dolu sınavlar ve okul bittiğinde uzaklaşılmak istenen, hayatı kabusa çeviren bir ders olarak görülmektedir (Sertöz, 1999). Bu algıların ise öğrencilerin matematikteki başarılarını etkilediği bilinmektedir (Alkan, 2010). Nitekim öğrencilerin matematik öğrenmelerinde bilişsel özellikler kadar matematiğe yönelik olumlu tutum, 
motivasyon, inanç gibi duyuşsal özelliklerin önemli bir yeri olduğu belirtilmektedir. Motivasyon ise öğrencilerin bilişsel öğrenmelerinin ön şartlarından biri olarak görülen en etkili duyuşsal özelliklerden biridir (Açıkgöz, 2003; Bacanlı ve Şahinkaya, 2011; Balantekin ve Bilgin, 2017; Demir ve Budak, 2016; Ergin \& Karataş, 2018; Lazowski \& Hulleman, 2016; Müezzin \& Özata, 2019; Vallerand ve diğ., 1992). Bu açıdan, matematik öğrenme konusunda yüksek motivasyona sahip olan öğrencilerin, matematiği daha iyi öğrenerek daha başarılı olacakları düşünülmektedir (Akçakın, 2018).

Matematik öğrenmede önemli bir duyuşsal özellik olarak nitelendirilen motivasyon tanımların birinde "okuldaki öğrenci davranışlarının yönünü, şiddetini, kararlılığını ve eğitim ortamlarında istenilen amaca ulaşmadaki hızı belirleyen önemli bir güç kaynağı” (Akbaba, 2006 s.343) şeklinde ele alınırken, Pintich ve Schunk (2002) tarafından bireyin bir işi gerçekleştirirken çaba göstermesi, ısrarcı olması ve beceri yönetimi göstermesi şeklinde tanımlamıştır. Buradan hareketle motivasyonun bireyin davranışlarının başlamasında, sürdürmesinde ve akademik başarıyı elde etmesinde etkili bir yeri olduğu söylenebilir (Bruinsma, 2003; Glynn, Aultman \& Owens 2005; Martin, 2001; McKenzie \& Schweitzer, 2001).

Öğrencilerin motivasyonlarındaki gelişim erken yaşlarda hatta doğum öncesinde başlamakla birlikte aile ve okul ortamları ise motivasyonun artması ve süreklilik göstermesinde etkin rol almaktadır (Köyceğiz \& Özbey, 2019; Linder, Smart \& Ciribbs, 2010). Bu nedenle öğrencilerin matematiği öğrenmeye başladığı andan itibaren matematiğe yönelik motivasyonlarını geliştirecek uygulamalar yapmanın önemli olduğu düşünülmektedir. (Pintrich ve Schunk, 1996; Stipek, 1996). Bu uygulamalarda ise matematik tarihi (MT) destekli etkinlikler kullanılabilir. Nitekim MT’nin, matematik öğrenmeye ilham veren büyük bir motivasyon aracı olduğu belirtilmiştir (Carter, 2006; Fauvel, 1991; Liu, 2003; Rickey, 1995; Tzanakis ve diğ., 2002). Ayrıca Deci, Spiegel, Ryan, Koestner ve Kauffman’a (1982) göre öğretmenlerin öğrencilerin matematiksel fikirlere aktif katılımını ve matematik kavramlarının kişisel inşasını desteklemesi, öğrencilerin daha fazla özerkliği, bağımsızlığı ve matematikte daha fazla içsel ilgiyi teşvik etmesi gerekliliği üzerinde durmuşlardır. Çünkü bu durumun öğrencilerin motivasyonlarını arttırma adına etkili olabileceği görüşü hakimdir. Buradan yola çıkarak MT’nin matematik derslerinde öğrencilere özerklik verecek etkinlikler yapmaya elverişli olması büyük bir motivasyon aracı olduğunun göstergesidir. Aynı zamanda öğrenciler ilgi çekici ve merak uyandırıcı konuları daha hızlı ve kolay öğrenme eğiliminde olduklarından, MT’de yer alan çeşitli içeriklere yönelik ilgi 
Matematik Tarihi Destekli Matematik Derslerine Yönelik Motivasyon Ölçeğinin Geliştirilmesi: Geçerlik ve Güvenirlik Çalışması duydukları ve zevk aldıkları takdirde, matematiğe yönelik motivasyonların da artabileceği düşünülmektedir. $\mathrm{Bu}$ bağlamda motivasyonun artması ise öğrencilerin matematik başarılarını arttırabilmektedir (Akbaba, 2006). Alanyazına bakıldığında MT’nin çeşitli yollarla öğrencilerin motivasyonlarını arttırmada etkili olduğu görülmektedir (Başıüyük \& Şahin, 2019; Bütüner, 2016; Bütüner, 2018; Ernest, 1998; Farmaki \& Paschos, 2007; Fauvel, 1991; Jankvist, 2010; Liu, 2003; Marshall \& Rich, 2000; Mersin, 2019; NCTM, 2006; Philippou \& Christou, 1998). Örneğin bir öğrenci ikinci dereceden denklemlerin çözümünü anlamamış ve bu yüzden o derse karşı ilgisini kaybetmiş olabilir. Ancak ikinci dereceden denklemlerin çözümünde ek olarak Harezmi'nin kareye tamamlama metodu gibi geometrik bir çözüm yolunun kullanılması öğrencilere farklı bakış açısı sunacağı ve belki de öğrencilerin daha kolay anlamalarını sağlayacağı için öğrencilerin o derse yönelik motivasyonunun artmasında etkili olabilir. Nitekim tek bir doğru çözümü bulmaktan ziyade sürece ve alternatif çözümler aramaya daha fazla önem verilmesi, çocukların performans (doğru yapmak), sosyal onay (öğretmeni memnun etmek) veya notlardan ziyade ustalık ve anlayış geliştirmeye odaklanmalarına yardımcı olabilir (Stipek, Givvin, Salmon \& Macgyvers, 1996). Ünlü matematikçilerin karşılaştıkları zorluklara rağmen matematiği araştırmaktan vazgeçmemesi ve sonunda başarıya ulaşması ya da ünlü matematikçilerin de keşifleri sırasında zaman zaman hataya düştükleri yönünde verilen örnekler öğrencilerin matematiğin bir insan ürünü olduğu, kendilerinin de hata yapabilecekleri ancak pes etmeden çalıştıkları takdirde başarıya ulaşabileceklerine dair algılar oluşturarak motivasyonlarının artmasında etkili olabilir (Fauvel, 1991; Mersin, 2019; Philippou \& Christou, 1998). Bu duruma ise Hippasus'un hikayesinin anlatılması örnek verilebilir. Nitekim irrasyonel sayıların var olduğunu ispatlaması hayatına mal olmuştur. MT'nin öğrencilerin motivasyonlarını arttırmasına bir başka örnek olarak ise öğrencilerin kavramların tarihsel gelişimlerini öğrenmeleri, matematikle ilgili büyük resmin görülmesini sağlayarak öğrencilerin matematiği anlamlandırmalarını kolaylaştırmasıdır (Burns, 2010; Farmaki \& Paschos, 2007; Fauvel \& van Maanen, 2002; Furinghetti, 2000; Göktepe \& Özdemir, 2013; Jankvist, 2009; Mac an Bhaird, 2009; Marshall, 2000). Şu an kullandığımız rakamların ve cebirsel sembollerin (x sembolü gibi) nasıl bir süreçten geçerek şimdiki hali aldığı, pi sayısının hesaplanmasında hangi süreçlerin geçtiği, hangi metotların kullanıldığı, yapılan hatalar ve alternatif yaklaşımlar büyük resmin görülmesinde etkili olduğu gibi öğrencilerin MT'ye ve matematiğe yönelik motivasyonlarının artmasını sağlayabilir. Öğrencilere pisagor teoremini öğretirken bu teoremin Pisagor'dan çok önce Babiller döneminde kullanıldığı belirtilerek buna 
kanıt olaraki se Plimpton 322 tabletinin öğrencilere tanıtılması yine öğrencilerin motivasyonunu arttırma yollarından biri olarak gösterilebilir. Ayrıca öğrencilerin motive olduklarında daha iyi öğrendikleri ve öğrenme sürecinde matematiksel kavramların tarihinin kullanılmasının, öğrencilerin motive olmasına ve daha fazla öğrenmek ve keşfetmek istemesine yardımcı olabileceği belirtilmiştir (Arcavi \& Isoda, 2007; Carter, 2006; Haverhals \& Roscoe, 2010; Lim \& Chapman, 2015; Nataraj \& Thomas, 2009).

Jankvist (2009) MT’nin öğrencilerin motivasyon kazanmalarında yardımcı olduğunu, öğrencilerin matematik bilişlerini güçlendirdiğini bu sebepten dolayı MT'nin matematik derslerinde kullanılması gerektiğini belirtmiştir. MT'nin matematik derslerinde farklı şekillerde kullanılabileceği ve bunun da öğrencilerin motivasyonlarının artmasında etkili olabileceği düşünülmektedir. Matematik derslerinde ünlü matematikçilerin hayat hikayelerine, eserlerine ve resimlerine yer verilmesi bu yollardan biridir (Tzanakis ve diğ., 2002). Eskiden kullanılan rakamlara, sayı sistemlerine, Antik Çağ'da çözülemeyen üç ünlü probleme (küpün iki katına çıkarılması, bir açının üç eşit açıya bölünmesi, çemberin kareselleştirilmesi) yer verilmesi öğrencilerin dikkatini derse çekmede etkili faktörlerdendir. Bunun yanında Tzanakis ve diğerleri’ne (2002) göre öğrencilere derste tarihsel matematiksel oyunların oynatılması, matematik tarihiyle ilgili filmler ve belgeseller izletilmesi, doğada ve mimaride matematiğin keşfi amaciyla açık hava deneyimlerinin yaşatılması öğrencilerin matematiğe yönelik motivasyonlarını arttırmada etkili yöntemler arasında gösterilebilir. Bununla birlikte Reimer ve Reimer'in (1995) öne sürdüğü sınıfta yüksek sesle MT'den hikayelerin okunması, öğrencilere MT ile ilgili oyunlar oynatılması, skeçler yaptırılması ve videoların izletilmesi, uygulamalı deneyimler yaptırılması ve sanatsal yollar, dersi monotonluktan uzaklaştırarak öğrencilerin ilgisini canlı tutmasını ve matematik derslerine motive olmuş şekilde katılmalarını sağlayabilir.

MT’nin öğrencilerin motivasyonlarını arttırmasına yönelik çeşitli çalışmalar yapılmıştır. Örneğin Haverhals ve Roscoe (2010) sekant kavramının integralini tarihsel bir yol aracılığıyla öğretmenin yararlarını araştıran bir çalışma yapmıştır. Çalışma 16 lisans öğrencisi ile gerçekleştirilmiştir. Çalışma sonucunda MT kullanımının öğrencilere ilham, içgörü ve motivasyon kaynağı sağladığı yönünde görüş bildirmiştir. Ponza (1998) tarafından yapılan bir nitel çalışmada ise Fransız bir matematikçinin hayatıyla ilgili bir proje üzerinde çalışıldıktan sonra öğrencilerin daha iyi tutum ve motivasyon sergilediği görülmüştür. Bir başka çalışmada ise öğrencilerin MT'deki matematikçilerin biyografileri üzerine çalışma yapıldıktan sonra matematiğe yönelik 
Matematik Tarihi Destekli Matematik Derslerine Yönelik Motivasyon Ölçeğinin Geliştirilmesi: Geçerlik ve Güvenirlik Çalışması daha fazla motivasyona sahip oldukları belirlenmiştir (Dittrich, 1973). Ersoy ve Öksüz (2016) çalışmalarında matematik derslerinde MT kullanılmasının dördüncü sınıf öğrencilerinin motivasyonlarını arttırdığı sonucuna ulaşmışlardır. Lim ve Chapman (2015), 11. sınıf öğrencileri ile yaptığ 1 deneysel çalışma sonucunda MT etkinliklerinin yapıldığg deney grubunda öğrencilerin matematiğe yönelik motivasyonlarının arttığını belirlemişlerdir.

MT’nin öğrencilerin ilgilerini çekecek, matematiği sevdirecek zengin bir kaynak olduğu düşünüldüğünde, öğrencilerin motivasyonlarını arttırma adına etkili olduğu görülmektedir. Ancak bu etkinin anlamlı olup olmadığını ölçecek nicel araçların ulusal ve uluslararası alanyazında eksik olduğu belirlenmiştir. Alanyazına bakıldığında aşağıda ayrıntılı açıklamalarının verildiği matematiğe ve matematik derslerine yönelik motivasyon ölçeklerinin olduğu görülmektedir. Ancak bunlar MT ile ilgili ölçekler değildir. Yalnızca matematiğe veya matematik derslerine yöneliktir. Aktan ve Tezci (2013) beşinci sınıf öğrencileri için öğrenmede motive edici stratejiler ölçeğinin (Motivated strategies for learning questionnaire) bazı maddelerinin Türkçe'ye adapte edilmesi ile matematik motivasyon ölçeği (MMÖ) geliştirilmiştir. MMÖ, içsel hedef yönelimi, dışsal hedef yönelimi, konu değeri, öğrenme inançları, öz yeterlik ve sınav kaygısı şeklinde alt boyutları ve .91güvenirliğe sahip olan bir ölçektir. Balantekin ve Oksal (2014) tarafından ilkokul üçüncü ve dördüncü sınıf öğrencileri için 14 maddeden oluşan matematik dersi motivasyon ölçeği geliştirilmiştir. Bu ölçeğin alt boyutları ise içsel motivasyon, dışsal motivasyon ve motivasyon yoksunluğu şeklindedir. Dede ve Argün (2004) yedinci sınıf öğrencileri için içsel ve dışsal motivasyon olarak iki alt boyuta sahip 26 maddeden oluşan bir ölçek geliştirmişlerdir. Ölçeğin güvenirlik katsayısı ise .82'dir. Ersoy ve Öksüz (2015) üçüncü ve dördüncü sınıf öğrencileri için 33 maddeden oluşan tek faktörlü .94 güvenirlik katsayısına sahip bir ölçek geliştirmişlerdir. Hussien (2011) öz belirleme kuramına dayalı olarak dördüncü sınıftan on ikinci sınıfa kadar kullanılabilen bir motivasyon ölçeği geliştirmiştir. Otuz sekiz maddeden oluşan ölçeğin faktörleri içsel motivasyon, içe dönük düzenleme, dişsal düzenleme ve motivasyon yoksunluğu şeklindedir. Lim ve Chapman (2015) akademik motivasyon ölçeği'ni (AMS) matematiğe adapte ederek 11. ve 12. sınıf öğrencileri için matematiğe yönelik akademik motivasyon ölçeği geliştirmişlerdir. Öz belirleme kuramı temel alınarak geliştirilen bu ölçek 28 madde olup motivasyon yoksunluğu, dışsal düzenleme, içedönük, özdeşleştirme ve içsel motivasyon alt boyutlarından oluşmaktadır. Linder, Smart ve Cribbs (2010) 17 maddeden oluşan ve .849 güvenirlik katsayısına sahip ilkokul matematik motivasyon ölçeği geliştirmiştir. Plenty ve Heubeck (2013) ise Martin'in (2007) lise 
öğrencileri için akademik motivasyon ve katılım ölçeğini yedinci, sekizinci ve dokuzuncu sınıf öğrencileri için matematik dersine uyarlayarak matematik motivasyon ölçeği geliştirmiştir. Oie ve Fujie (2007) Japonca matematik motivasyon ölçeği geliştirmişlerdir. Bu ölçek 20 maddeden oluşmuş olup ilkokul ve ortaokul öğrencilerine uygundur. Orosco (2014) ikinci ve üçüncü sınıf öğrencilerine yönelik 10 maddeden oluşan ve güvenirliği 85 olan bir ölçek geliştirmiştir. Tahiroğlu ve Çakır (2014) ilkokul dördüncü sınıf öğrencileri için güvenirlik katsayısı .91 olan 32 madde ve beş faktörlü matematik motivasyon ölçeği geliştirmişlerdir. Kesici (2018) ise lise öğrencileri için amaç yönelimi, beklenti değer ve özyeterlik alt boyutlarına sahip 12 maddeden oluşan bir ölçek geliştirmiştir.

$\mathrm{Bu}$ ölçekler incelendiğinde genellikle ilkokul öğrencileri için hazırlandığı dolayısıyla ortaokul öğrencileri için alanyazında eksiklik olduğu görülmektedir. Bununla birlikte bu çalışmanın merkezinde MT destekli matematik dersleri olduğu için MT’ye yönelik veya MT destekli matematik derslerine yönelik herhangi bir motivasyon ölçme aracına rastlanmamıştır. Ayrıca ölçeklerin birisi hariç (Balantekin \& Oksal, 2014) bu ölçekte ele alınan ölçek boyutları olan içsel motivasyon, dişsal motivasyon ve motivasyon yoksunluğunu bir arada incelenmemiştir. Dolayısıyla geliştirilen MT-MMÖ (matematik tarihi destekli matematik derslerine yönelik motivasyon ölçeği) ile birlikte ortaokul öğrencilerinin MT destekli matematik derslerine yönelik motivasyonlarının artıp artmadığı veya MT-MMÖ’nün maddelerine dayanarak MT ile ilgili hangi durumlarda öğrencilerin motive oldukları belirlenerek (içsel, dışsal veya motive olmama) bu sonuçların öğretmenlere rehber olabileceği düşünülmektedir. Nitekim öğretmenler öğrencilerin MT kullanımıyla motive olma durumlarını bildiklerinde öğrenme sürecini buna göre şeklilendirebileceklerdir (Çakmak \& Ercan, 2006). Bu durum ise öğrencilerin aktif olarak derslere katılmalarına, öğrendiklerini önceki bilgilerle ilişkilendirerek sorular sormalarına teşvik edebilecektir. MT vasıtasıyla motive olan öğrenciler ise boş zamanlarında bile kendi istekleri ile çalışmalar yapabilecek ve farklı öğrenme metotları geliştirebileceklerdir (Schunk, 2009). Bununla birlikte motivasyon ile başarı arasında pozitif bir ilişkinin olduğu bilinmekte (Yunus \& Ali, 2008; Üredi \& Üredi, 2005) ve öğrencinin başarıya ulaşabilmesi için tam anlamıyla motive olması gerektiği belirtilmektedir (Hodges, 2004). Bu bağlamda öğrencilerin MT- MMÖ kullanılarak MT ile motive olan öğrencilerin tespiti matematikte başarılı olabilme imkanını elde etmelerine aracı olabilecektir (Linder, Smart \& Cribbs, 2010). Bu bağlamda öğrencilerin MT destekli matematik 
Matematik Tarihi Destekli Matematik Derslerine Yönelik Motivasyon Ölçeğinin Geliştirilmesi: Geçerlik ve Güvenirlik Çalışması derslerine yönelik motivasyonlarının belirlenmesi dolayısıyla bunu belirleyecek bir ölçeğin geliştirilmesi önemli görülmektedir.

\section{Kuramsal Çerçeve}

Öğrenmeyi etkileyen en önemli bileşenlerden biri olan motivasyon (Balantekin \& Oksal, 2014; Deringöl, 2018; Elliot \& Dweck, 2005; Kesici, 2018; Lazowski \& Hulleman, 2016; Süren, 2019; Tahiroğlu \& Çakır, 2014), Feldman (2005) tarafından insanların ve diğer organizmaların davranışlarını yönlendiren ve enerji sağlayan faktörler, Wood (2002) tarafından ise fizyolojik ve psikolojik ihtiyaçları karşılamak için davranışları başlatan, yöneten ve sürdüren bir süreç olarak tanımlanmıştır. Bu bağlamda motivasyon, bireyin bir amaca ulaşma yönünde istekli davranışlar sergileme ve bu davranışları devam ettirebilme, karşısına çıkan engellerle başa çıkabilmede etkili bir güçtür. Matematiğe yönelik motivasyon ise, öğrencilerin matematik öğrenmeye gönüllü olmas1, matematiksel etkinliklere katılması ve bu davranışlarının sürdürülmesi olarak tanımlanabilir (İspir, Ay \& Sayg1, 2011; Moddleton, 2014).

Alanyazın incelendiğinde motivasyon ile ilgili olarak çok sayıda teorinin olduğu görülmektedir. Bunlar ise çeşitli kategoriler altında sınıflandırılmıştır. Bu kategoriler genel olarak davranışcı, hümanistik ve bilişsel kuramlar başlıkları altında incelenmektedirler (Öksüz, 2015). Davranışcı kuramlar, ödül ve cezayı, hümanistik kuramlar bireylerin gelişimini ve gereksinimlerini (Pintrich \& Schunk, 2002), bilişsel kuramlar ise bireylerin beklenti, inanç ve çevrenin anlaşılmasını temel almaktadır. Bilişsel öğrenme üzerinde etkili olduğu bilinen motivasyonun (Akçakın, 2018) eğitim alanlarında çoğunlukla bilişsel kuramlarının kullanıldığı görülmektedir. Bu bilişsel kuramlar ise beklenti değer, öz yeterlik, ilişkilendirme ve özbelirleme kuramları olarak gruplanmaktadır. Bilişsel motivasyon türlerinden özbelirleme kuramına göre, öğrencilerin motivasyonlarını arttırmak için üç temel ihtiyacın karşılanması gerekli görülmektedir. Bunlar özerklik, ilişki ve yeterlilik şeklindedir. (Utvær \& Haugan, 2016). Nitekim bireylerin davranışlarını özgürce seçtikleri (yani özerklik), başkalarıyla yakın ilişkilere sahip oldukları (yani ilgili oldukları) ve üstlendikleri faaliyetlerde etkili olduklarını (yani yeterlik) hissetmelerinin gerektiği üzerinde durulmuştur (Utvær \& Haugan, 2016). Bununla birlikte öz belirleme kuramında bireylerin davranışlarının özerk ya da kontrollü olup olmadığını bilmenin, genel motivasyon miktarından çok 
daha önemli olduğunu savunulmakta ve özerk motivasyon yüksek kaliteli motivasyon olarak kabul edilirken, kontrollü motivasyonun düşük kalitede olduğu düşünülmektedir (Deci \& Ryan, 2000).

Öz belirleme kuramı, öğrenmede içselleştirmenin ve öğrencilerin, öğretmenleri tarafından temel psikolojik desteklerini hissetmelerinin önemli olduğu, öğretmenlerin öğrenci özerkliğini destekleyen uygulamalara ağırlık vermesi gerektiği, öğretmenlerin öğrencilere seçenekler sunduğu, ilişkiler kurmaya odaklanmalarını sağlayacak görevler vermeleri gerektiği üzerinde odaklanmaktadır (Lazowski ve Hulleman, 2016; Utvær \& Haugan, 2016).

MT etkinliklerinin;

- öğrencilere matematiksel problemlere yönelik farklı öğrenme yolları sunması (örn. Çin kalan teoremi),

- farklı bakış açıları kazandırması (matematiğin insani yönünü göstermesi),

- kavramların gelişim süreçlerini öğrenerek geçmişle şimdi arasında ilişki kurmasını sağlaması (pi sayısının gelişim süreci),

- öğrencilerin işbirliği içinde çalışmasına olanak vermesi (araştırma prolejeri),

- öğrenci merkezli öğrenmeye ve öğrencilerin öğretmene bağlı olmadan özerk bir şekilde öğrenmelerine olanak vermesi sebebiyle,

ayrıca ortaokul öğrencilerinin MT etkinlikleriyle geçekleştirilen matematik derslerine katılım, başarılı olma isteği, etkileşim kurmaya gönüllülük gibi durumlarda motivasyonlarının olup olmadığını veya ne düzeyde olduğunu belirlemek için Deci ve Ryan'nın (1985) geliştirdiği öz belirleme kuramı temel alınarak göre MT-MMÖ’nün geliştirilmesi amaçlanmıştır.

Özbelirleme kuramına göre motivasyon, içsel motivasyon, motivasyon yoksunluğu ve dışsal motivasyon olarak üç bileşenden oluşmaktadır (Deci, Vallerand, Pelletier \& Ryan, 1991; Ryan \& Deci, 2000;). İçsel motivasyon, öğrencilerin bir etkinliğe katılma ve etkinliğin gerçekleşmesiyle ulaşılan haz ve doyum olgusu (Vallerand \& Senecal, 1992'den Akt., Viau, 2009), öğrenmeye katılma ve öğrenmeyi sürdürme isteği (Middleton \& Spanias, 1999); hoşuna giden etkinlikleri kendi iyiliği için gerçekleştirmesi (Kılıç \& Y1lmaz, 2019), içsel gereksinimlerine ilişkin davranışları (Ersarı \& Naktiyok, 2012), öğrenmeye duyulan merak ve başarmanın verdiği haz (Deci \& Ryan, 1985) olarak araştırmacılar tarafından farklı şekillerde tanımlanmıştır. İçsel motivasyonun ilişkisellik, özerklik ve yeterlik ihtiyaçlarının karşılanmasıyla ilişkili olduğu (Ryan \& Deci, 2000) 
Matematik Tarihi Destekli Matematik Derslerine Yönelik Motivasyon Ölçeğinin Geliştirilmesi: Geçerlik ve Güvenirlik Çalışması ve kaynağının kişinin ilgisi, yeterli olma, bilme ve merak hislerinden oluştuğu belirtilmektedir (Akbaba, 2006). Eğitim ortamında öğrencilerin kendilerini daha özerk hissettikleri durumlarda içsel motivasyonlarının geliştiği gözlemlenirken, somut ödüllerin, cezaların, sosyal çevre baskısının içsel motivasyonun azalmasına neden olduğu belirlenmiştir (Ryan \& Deci, 2000). İçsel motivasyon öğrencilerin bilişsel ve sosyal gelişimlerinde önemli bir role sahip olmakla birlikte içsel motivasyona sahip bir öğrencinin dersi dikkatli dinlemesi, başarılı olmak için çalışmalarında süreklilik ve karşılaşılan zorluklarla başa çıkmada kararlılık göstermesi beklenmektedir (Driscoll, 2012; Ryan \& Deci, 2000) Bir öğrencinin okul veya aile çevresinin kendi üzerinde hiçbir baskıs1 olmadan ya da herhangi bir not kaygısı olmadan, tamamen kendisinin sevmesi, ilgi duyması veya başarma hissi sebebiyle bir dersi daha fazla çalışması veya bu dersle ilgili çeşitli sorumluluklar alması içsel motivasyona örnek olarak gösterilebilir. MT açısından bakıldığında ise bir öğrencinin MT'nin problemlere farklı çözüm yollar sunmasının ve kavramların tarihsel gelişimlerinin hoşuna gitmesi, MT'de yer alan çözümü bulunamayan zorlayıcı problemlerle uğraşmayı sevmesi gibi sebeplerle daha fazla matematik çalışması içsel motivasyona örnek verilebilir. Örnekte de görüldüğü gibi içsel motivasyonda öğrenci MT’yi sevdiği, hoşuna gittiği için matematiği daha fazla çalışırken, dışsal motivasyonda dış nedenlerden dolayı matematiği çalışma söz konusudur. Bir diğer ifadeyle öğrenci ilişkisiz bir sonuç için bir faaliyette bulunmak istemektedir (Ryan \& Deci, 2000).

Dışsal motivasyon bireyin dişından gelen etkileri içermekle birlikte ceza ve ödüllere dayanmaktadır (Ayık, Ataş Akdemir \& Seçer, 2015) Dışsal motive olmuş öğrenciler, öğretmenlerinden, arkadaşlarından veya ebeveynlerinden kendi yeterlikleri ile ilgili olumlu yönde değerlendirmeler almak, cezadan veya eleştirilerden kaçınmak gibi dışsal kaynaklı nedenlerden dolayı etkinliklere katılmaktadırlar (Duda \& Nicholls, 1992; Middleton \& Spanias, 1999). Öğrencilerin, öğretmeni ve arkadaşları karşısında iyi bir öğrenci profili çizmek istemesi, düşük not almamak veya dersten kalmamak için ders çalışması, öğretmenlerinin ve ailesinin takdirini kazanmak istemesi gibi durumlar dışsal motivasyona örnek gösterilebilecek durumlardır. Sınıfta MT ile yapılan etkinliklerde başarılı olan öğrencileri öğretmeninin takdir etmesi ve bir başka öğrencinin de bu takdiri kazanmak istemesi, MT’de iyi olan bir öğrencinin matematik sınavından yüksek puan alması ve bir diğer öğrencinin de yüksek not almak amacıyla MT ile ilgili etkinliklere daha fazla katılmaya başlaması dışsal motivasyona örnek olarak gösterilebilir. 
Dışsal motivasyon içsel motivasyona göre öğrencileri daha az etkilemektedir. Nitekim dışsal motivasyonda dışarıdan birinin takdir veya teşekkürüne gereksinim duyulurken, içsel motivasyonda kişinin kendi isteği ve haz duygusu öne çıkmaktadır. Ancak her öğrencinin içsel motivasyona sahip olamayacağı düşünülürse bu noktada devreye dişsal motivasyon girmektedir ki dışsal motivasyonun öğrencilerin içsel motivasyon kazanmasında etkili olduğu bilinmektedir (Akbaba, 2006). Bununla birlikte öğrencilerin içsel ve dışsal motivasyon kaynakları zamanla değişebilmektedir. Örneğin bir öğrenci matematik derslerindeki MT etkinliklerine başlarda öğretmeninin veya arkadaşlarının dikkatini çekme, onlardan övgü almak gibi sebeplerden dolayı katılırken, daha sonraları MT etkinliklerinden keyif alması halinde sadece sevdiği için bu etkinliklere katılabilmekte ve başta dişsal motivasyon kaynağı olan MT içsel motivasyon kaynağı haline gelebilmektedir. Ya da başta yalnızca hoşuna gittiği için MT etkinliklerine katılan bir öğrenci MT’nin matematik derslerine entegrasyonunun zamanla sıkıcı bir hal alması (sözel ifadelerin artması, geçmişteki kavram ve sembollerin karmaşık gelmesi, sınav stresi vs.) gibi nedenlerden dolayı artık yalnızca matematikte başarılı olmak için MT etkinliklerine katılması halinde içsel motivasyon kaynağı dişsal motivasyon kaynağı haline dönüşebilmektedir (Schunk, 2009).

Son motivasyon türü olan motivasyon yoksunluğu ise, her tür motivasyonun yokluğu (Vallerand \& Senecal, 1992) anlamına gelmekle birlikte, bu aşamada birey eylemler ve sonuçları arasında bir ilişki kuramamaktadır (Akt., Viau, 2009). Motivasyon yoksunluğu öğrencilerin, bir davranışı gerçekleştirme adına kendini yeterli hissetmemesi veya istediği sonuca ulaşamayacağı düşüncesine sahip olması, maddi veya manevi ödüllere önem vermemesi, eylemleri üzerinde kontrol edebilme eksikliği, bir göreve verilen değer eksikliği gibi nedenlerden kaynaklanabilmektedir (Deci \& Ryan, 2000). Örneğin öğrencilerin MT ile matematik arasında bir ilişki kuramaması MT destekli matematik derslerine yönelik motivasyon yoksunluğu yaşamasına neden olabilir. Motivasyon yoksunluğu, bireylerin bir davranışı sonraki sonuçlarla ilişkilendirmediği bir durum olarak tanımlanmıştır ve bu nedenle davranışlar bilinmeyen veya hiç yürütülmeyen nedenlerle yürütülür (Deci \& Ryan, 1985).

Öz belirleme kuramına göre öğrencilerin MT destekli matematik derslerinde matematiğe yönelik içsel motivasyon, dışsal motivasyon veya motivasyon yoksunluğu yaşadıklarının belirlenmesi ve belirlenen sonuçlara göre öğrencilerin motivasyon derecelerini veya kalitelerini 
Matematik Tarihi Destekli Matematik Derslerine Yönelik Motivasyon Ölçeğinin Geliştirilmesi: Geçerlik ve Güvenirlik Çalışması (içsel, dışsal) yükseltmek amacıyla öğretmenlere rehber oluşturması açısından matematik tarihi destekli matematik derslerine yönelik motivasyon ölçeğinin (MT-MMÖ) geliştirilmesi amaçlanmıştır.

\section{Yöntem}

\section{Araştırmanın Modeli}

Ortaokul öğrencilerinin MT destekli matematik derslerine yönelik motivasyonlarını ölçmeye ilişkin bir ölçeğin geliştirilmesinin amaçlandığı bu çalışmada De Vellis'in (2016) ileri sürdüğü madde havuzu oluşturma, kapsam ve görünüş geçerliğinin sağlanması, uygulama, yap1 geçerliğinin sağlanması ve güvenirlik hesaplama aşamalarını kapsayan ölçek geliştirme süreçleri takip edilmiştir.

\section{Örneklem}

Bu çalışma 2017-2018 eğitim öğretim yılının ikinci döneminde Bolu il merkezinde yer alan MEB'e bağlı orta düzey başarıya ve sosyoekonomik düzeye sahip iki devlet okulunda öğrenim gören 97 beşinci, 101 altıncı, 100 yedinci ve 99 sekizinci sınıf öğrencisi olmak üzere 397 öğrenci ile gerçekleştirilmiştir. Örneklemin seçiminde uygun örnekleme yöntemi kullanılmıştır. Uygun örnekleme yöntemleri zaman, para ve işgücü açısından kazanç sağlama amacıyla seçilen ancak yanlı olma ihtimali yüksek bir yöntemdir. Uygulama yapabilmek için zamanın kısıtlı olmasından dolayı bu yöntemin tercih edilmiştir.

Katılımcıların sınıf düzeyi ve cinsiyetlerine göre dağılımları ise Tablo 1'de verilmiştir.

Tablo 1. Öğrencilerin Sınıf Düzeyi ve Cinsiyetlerine Göre Dă̆llımları

\begin{tabular}{llllll}
\hline Cinsiyet & \multicolumn{5}{c}{ Sinıf Düzeyi } \\
\cline { 2 - 6 } & 5 & 6 & 7 & 8 & Toplam \\
\cline { 2 - 6 } Kız & 50 & 48 & 55 & 49 & 202 \\
Erkek & 47 & 53 & 45 & 50 & 195 \\
Toplam & 97 & 101 & 100 & 99 & 397 \\
\hline
\end{tabular}




\section{MT-MMÖ’nün Geliştirilme Süreci}

Ölçeğin geliştirilmesi aşamasında, motivasyon, matematiğe yönelik motivasyon, matematik tarihine yönelik tutum ve motivasyon konularına yönelik yurt içi ve yurt dışında geliştirilmiş olan ölçekler incelenmiştir (Alpaslan, 2011; Balantekin \& Oksal, 2014; Bütüner \& Baki, 2011; Dede \& Argün, 2004; Dede \& Yaman, 2008; Dinçer \& Doğanay, 2016; Ersoy \& Öksüz, 2015; Lim \& Chapman, 2015; Panasuk \& Horton, 2012; Panasuk \& Horton, 2013). Bu doğrultuda ölçekte yer alabilecek alt boyutların ve maddelerin neler olabileceği belirlenmiştir. Ölçeğe ilişkin madde havuzu Deci ve Ryan'ın (1985) öz belirleme teorisinde bulunan içsel motivasyon, dışsal motivasyon ve motivasyon yoksunluğu bileşenleri göz önünde bulundurularak hazırlanmıştır. $\mathrm{Bu}$ bağlamda 99 maddeden oluşan madde havuzunda 56 madde içsel motivasyon, 23 madde dışsal motivasyon, 20 madde ise motivasyon yoksunluğu ile ilgili yazılmıştır. Taslak ölçek 2 matematik tarihi, 3 matematik eğitimi, 3 ölçme değerlendirme ve 1 dil uzmanı tarafından incelenmiştir. Uzmanların görüşleri doğrultusunda bazı maddelerin cümle yapısı değiştirilmiştir. Örneğin "matematik tarihinin entegre edildiği matematik dersleri bana çok ilginç gelir çünkü matematik problemleri için çeşitli yollar bulurum" cümlesi "matematik tarihinin entegre edildiği matematik derslerinde problem çözümlerine yönelik çeşitli yollar bulduğum için bu ders bana ilginç gelir” şeklinde değiştirilmiştir. Bazı kelimeler ise öğrencilerin daha rahat anlayabileceği farklı kelimelerle değiştirilmiştir. Örneğin her maddenin başındaki "matematik tarihinin entegre edildiği matematik dersleri” ifadesi, öğrencilerin "entegre" kelimesini anlamayacağı düşüncesinden hareketle "matematik tarihi destekli matematik dersleri" ifadesi ile değiştirilmiştir. Sonrasında Bolu ilinde yer alan bir ortaokulda öğrenim gören rastgele seçilmiş 10 öğrenciye maddeler okutulmuş ve maddelerin anlaşılırlığı onaylanmıştır. Böylece ölçeğin kapsam ve görünüş geçerliği sağlanmıştır.

MT-MMÖ ölçeğinin maddeleri 5 dereceli likert tipinde hazırlanmış olup olumlu maddeler 5-4-3-2-1, olumsuz maddeler 1-2-3-4-5 şeklinde puanlanmıştır. Ölçek "tamamen katıllyorum", "çoğunlukla katılıyorum", "kararsızım", "çoğunlukla katılmıyorum" ve "hiç katılmıyorum" seçeneklerinden oluşmaktadır. Taslak ölçekten alınabilecek en düşük puan 99, en yüksek puan ise 495'tir. Taslak ölçek öğrencilere iki ders saatinde uygulanmıştır. Ölçeğin uygulanmasıyla ilgili öğrenciler bilgilendirilmiştir. 
Matematik Tarihi Destekli Matematik Derslerine Yönelik Motivasyon Ölçeğinin Geliştirilmesi: Geçerlik ve Güvenirlik Çalışması

Taslak ölçek 397 ortaokul öğrencisine uygulanmış ve ölçeğin yapı geçerliğini sağlamak amacıyla öncelikle AFA yapılmıştır. Sonrasında ise AFA ile belirlenen faktörlerde yer alan değişken grupların bu faktörleri gerektiği ölçüde temsil edip etmediğini belirlemek amacıyla DFA yapılmıştır. AFA için SPSS, DFA için de AMOS yazılımları kullanılmıştır. Son olarak ise ölçeğin güvenirlik katsayısı hesaplanmış ve ölçeğin son şekli oluşmuştur. Nihai ölçek 39 madde ve 3 faktörden oluşmuştur. Ölçek geliştirme süreci Tablo 2'de özet olarak belirtilmiştir.

Tablo 2. Ölçek Geliştirme Süreç Basamakları

\begin{tabular}{ll}
\hline Madde havuzu oluşturma & - Literatür inceleme \\
Kapsam ve görünüş geçerliğin sağlanması & - Madde havuzu oluşturma \\
Uygulama & - 8 alan uzmanı ve 1 dil uzmanı \\
Yapı geçerliğinin sağlanması & - 397 ortaokul öğrencisi \\
Güvenirlik hesaplama & - Açımlayıcı faktör analizi (AFA) \\
Ölçeğin son hali & - Doğrulayıcı faktör analizi (DFA)
\end{tabular}

\section{Veri Analizi}

Taslak MT-MMÖ’nün ortaokul öğrencilerine uygulanması sonrasında elde edilen veriler SPSS 20 paket programına atılmıştır. Böylece 397 öğrencinin MT-MMÖ’ye ilişkin veri seti oluşmuştur. Sonrasında olumsuz olan yirmi ölçek maddesinin puanları SPSS programı ile ters çevrilerek tekrar puanlanmıştır. Ardından veri setinde hatalı veya eksik girilmiş maddelerin olup olmadığına bakılmıştır. Analiz yapmaya hazır hale gelen veri setinin faktör analizi için uygunluğunu tespit etmek amacıyla KMO ve Bartlett test sonuçları incelenmiştir. Veri setinin analiz için uygun olduğuna karar verilmesinin ardından ise AFA yapılmıştır. AFA ile oluşan faktörlerin doğruluğunun test edilmesi amacıyla maksimum likelihood yöntemi kullanılarak AMOS 6 programında birinci düzey DFA yapılmıştır.

AFA ve DFA'nın farklı örneklemlerden toplanan veriler üzerinde gerçekleştirilmesi önerilse de bu analizlerin aynı örneklem üzerinde yapıldığı araştırmalar alanyazında yer almaktadır (Aytaçlı \& Gündoğdu, 2019; Kurnaz, 2019; Özgen \& Bayram, 2019; Şen, Demir, Teke \& Y1lmaz, 2020; Worthington \& Whittaker, 2006). Bununla birlikte Doğan, Soysal ve Karaman'a (2017) göre aynı örnekleme uygulanan ve aynı örneklemin ikiye bölünmesiyle farklı yarılara uygulanan AFA 
ve DFA'nın sonuçları benzerlik göstermektedir. Bu bağlamda ölçek madde sayısının fazla olması ve katılımcılara ulaşma güçlüğünden dolayı AFA ve DFA aynı örneklemden elde edilen verilere uygulanmıştır.

Ölçeğin yapı geçerliği AFA ve DFA ile sağlandıktan sonra ölçeğin güvenirliği için Cronbach $\alpha$ güvenirlik katsayısı hesaplanmıştır. Ölçeğin ayırt ediciliğini belirlemek amacıyla madde toplam korelasyon değerleri ve \%27'lik alt ve üst gruplar arasında ilişkisiz örneklemler t testi yapılmıştır.

\section{Etik Konular}

$\mathrm{Bu}$ araştırma Abant İzzet Baysal Üniversitesi Sosyal Bilimlerde İnsan Araştırmaları Etik Kurulunun 02/01/2018 tarihlİ 2018/01 sayılı kararı ile alınan izinle yürütülmüştür.

\section{Bulgular}

Ölçeğin geçerlik ve güvenirliğini sağlamak amacıyla, AFA, DFA ve madde analizleri yapılmış ve güvenirlik katsayısı hesaplanmıştır.

\section{Ölçeğin Yapı Geçerliliğine İlişkin Bulgular}

\section{Açımlayıcı Faktör Analizi}

AFA, ilişkili çok sayıdaki maddeyi bir araya getirerek birbirinden bağımsız daha az sayıdaki faktörler altında toplanmasını sağlayan bir yöntemdir. Bu nedenle MT-MMÖ’nün yapı geçerliğini sağlamak amacıyla ilk olarak AFA yapılmıştır (Tabachnick \& Fidell, 2007). AFA yapılabilmesi için öncelikle yeterli örneklem büyüklügüne ulaşılmış olma durumu araştırılmıştır. Alanyazın incelendiğinde Kass ve Tinsley (1979) örneklem sayısının 300’ün altında olması durumunda madde sayısının 5 ile 10 katı arasında olması gerektiğini, ancak 300’ün üzerinde olması durumunda madde sayısına oranından bağımsız bir şekilde kararlı sonuçlara ulaşıldığını belirtmiştir. Bununla birlikte Comrey ve Lee (1992) faktör analizi için 50'nin zayıf, 300'ün iyi ve 1000 örneklemin çok iyi olduğunu belirtmiştir. Bu bağlamda bu çalışmada örneklemin 300’ün üzerinde olması dolayısıyla örneklem sayısı yeterli görülmüştür. Örneklem sayısının yeterliğini değerlendirmek için bir başka ölçüt ise Kaiser-Meyer-Olkin (KMO) testidir. KMO değerinin .60'ın üzerinde çıkması faktör analizi için yeterli bulunmaktadır (Field, 2005). Bu çalışmada ise KMO 
Matematik Tarihi Destekli Matematik Derslerine Yönelik Motivasyon Ölçeğinin Geliştirilmesi: Geçerlik ve Güvenirlik Çalışması değeri 945 olarak hesaplanmış olup istenen değerden oldukça yüksek çıkmıştır. Dolayısıyla bu değer faktör analizi için uygundur (Büyüköztürk, 2007). Veri setinin faktör analizi için uygun olup olmadığını belirleyen bir başka test ise Barlett's Test of Sphericity 'dir. Bu testin anlamlı çıkması verilerin çok değişkenli normal dağılımdan geldiği anlamına gelmektedir. Bu çalışmada ise Bartlett test sonucu anlamlı çıkmıştır $(\chi 2=26405.289 ; p<.05)$. Ayrıca anti-imaj matrisi incelenmiş ve tüm maddelerin .831 ve .969 aralığında dolayısıyla .5 'in üzerinde olduğu görülmüş ve örneklem yeterliği madde bazında değerlendirilmiştir (Pett, Lackey \& Sullivan, 2003)

MT-MMÖ’nün yapı geçerliğini sağlamak ve faktör yapısını belirlemek amacıyla Temel Bileşenler Analizi yöntemi ve varimax dik döndürme tekniği kullanılmıştır. Analiz sonucunda Tablo 3'te görüldüğü üzere maddelerin özdeğeri 1'den büyük olan 17 faktör altında toplandığı ve açıklanan varyansın \% 64.56 olduğu belirlenmiştir.

Tablo 3. Illk Faktör Analizi Sonucunda Oluşan Faktör Sayısı ve Varyans Değerleri

\begin{tabular}{|c|c|c|c|c|c|c|c|c|c|}
\hline \multicolumn{4}{|c|}{ Özdeğer } & \multicolumn{3}{|c|}{ Faktör Yükleri Kareler Toplamı } & \multicolumn{3}{|c|}{$\begin{array}{c}\text { Döndürülmüş Faktör Yükleri } \\
\text { Kareler Toplamı }\end{array}$} \\
\hline Bileşen & Özdeğer & $\begin{array}{c}\text { Varyans } \\
\%\end{array}$ & $\begin{array}{c}\text { Toplam } \\
\text { Varyans }\end{array}$ & Özdeğer & $\begin{array}{c}\text { Varyans } \\
\%\end{array}$ & $\begin{array}{c}\text { Toplam } \\
\text { Varyans }\end{array}$ & Özdeğer & $\begin{array}{c}\text { Varyans } \\
\%\end{array}$ & $\begin{array}{l}\text { Toplam } \\
\text { Varyans } \\
\end{array}$ \\
\hline 1 & 28.388 & 28.675 & 28.675 & 28.388 & 28.675 & 28.675 & 14.221 & 14.365 & 14.365 \\
\hline 2 & 11.268 & 11.382 & 40.057 & 11.268 & 11.382 & 40.057 & 12.497 & 12.623 & 26.988 \\
\hline 3 & 4.095 & 4.136 & 44.193 & 4.095 & 4.136 & 44.193 & 9.004 & 9.095 & 36.083 \\
\hline 4 & 2.821 & 2.849 & 47.042 & 2.821 & 2.849 & 47.042 & 3.379 & 3.413 & 39.496 \\
\hline 5 & 1.988 & 2.008 & 49.051 & 1.988 & 2.008 & 49.051 & 3.218 & 3.250 & 42.746 \\
\hline 6 & 1.789 & 1.808 & 50.858 & 1.789 & 1.808 & 50.858 & 3.189 & 3.221 & 45.967 \\
\hline 7 & 1.727 & 1.744 & 52.603 & 1.727 & 1.744 & 52.603 & 2.718 & 2.746 & 48.713 \\
\hline 8 & 1.458 & 1.472 & 54.075 & 1.458 & 1.472 & 54.075 & 2.190 & 2.212 & 50.925 \\
\hline 9 & 1.436 & 1.451 & 55.526 & 1.436 & 1.451 & 55.526 & 1.818 & 1.836 & 52.761 \\
\hline 10 & 1.273 & 1.286 & 56.812 & 1.273 & 1.286 & 56.812 & 1.654 & 1.671 & 54.432 \\
\hline 11 & 1.183 & 1.195 & 58.007 & 1.183 & 1.195 & 58.007 & 1.637 & 1.654 & 56.086 \\
\hline 12 & 1.163 & 1.174 & 59.182 & 1.163 & 1.174 & 59.182 & 1.536 & 1.552 & 57.638 \\
\hline 13 & 1.125 & 1.136 & 60.318 & 1.125 & 1.136 & 60.318 & 1.516 & 1.531 & 59.169 \\
\hline 14 & 1.104 & 1.115 & 61.433 & 1.104 & 1.115 & 61.433 & 1.513 & 1.528 & 60.698 \\
\hline 15 & 1.072 & 1.082 & 62.515 & 1.072 & 1.082 & 62.515 & 1.399 & 1.413 & 62.110 \\
\hline 16 & 1.023 & 1.033 & 63.548 & 1.023 & 1.033 & 63.548 & 1.218 & 1.230 & 63.340 \\
\hline 17 & 1.006 & 1.016 & 64.564 & 1.006 & 1.016 & 64.564 & 1.212 & 1.224 & 64.564 \\
\hline 18 & .997 & 1.008 & 65.572 & & & & & & \\
\hline
\end{tabular}

Şekil 1'de verilen yamaç- birikinti grafiğine bakıldığında ise dördüncü faktöre kadar hızlı bir düşüşün olduğu bu faktörden sonra ise grafiğin yatay bir seyir izlediği görülmüştür. Dolayısıyla faktör sayısının 3 veya 4 olabileceği düşünülmüştür. Bu kapsamda taslak ölçeğin teorik çerçevesi de göz önünde bulundurulduğunda faktör sayısının 3 olmasının uygun olacağı öngörülmüştür. Maddelerin faktör yük değerlerinin değerlendirilmesinde .4 eşik değer olarak kabul edilmiştir 
(Çokluk, Şekercioğlu ve Büyüköztürk, 2012). Bu doğrultuda ilk aşamada faktör yük değeri .40'ın altında olan maddeler (m17, m70, m62), faktör yükleri arasında .1 den az fark olan (Seçer, 2013, s. 130) ve birden fazla faktörde yükü olan binişik maddeler (m3, m4, m5, m6, m8, m9, m14, m15, m16, m19, m20, m27, m35, m39, m40, m41, m42, m43, m44, m45, m47, m51, m59, m60, m66, m67, m75, m77, m78, m82, m99), bir maddeden oluşan faktörlerdeki maddeler (m79, m31), iki maddeden oluşan faktörlerdeki maddeler (m64, m65, m22, m24, m80, m81, m21, m13) ç1karılarak tekrar faktör analizi yapılmıştır.

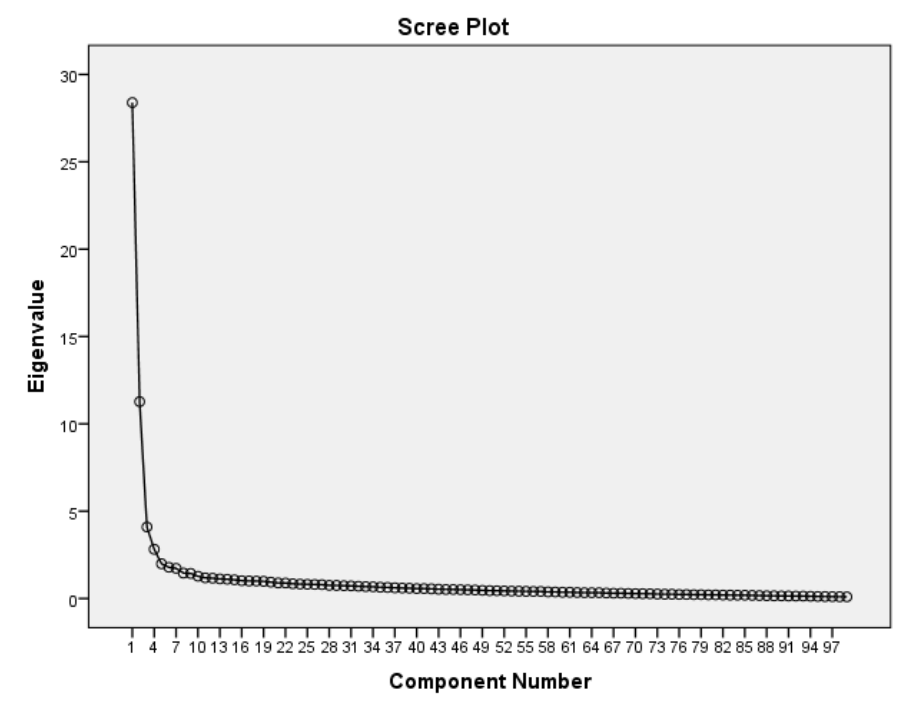

Şekil 1.İlk Faktör Analizine Ait Yamaç Birikinti Grafiği

İkinci faktör analizinde KMO değeri .949, Bartlett test sonucu ise anlamlı çıkmıştır. $(\chi 2=13486.684 ; \mathrm{p}<.05)$. Dolayısıyla veri seti faktör analizi için uygundur. Analiz sonucunda Tablo 4 'te görüldüğü üzere maddelerin özdeğeri 1'den büyük olan 8 faktör altında toplandığı ve açıklanan varyansın \%61.26 olduğu belirlenmiştir.

Tablo 4. İkinci Faktör Analizi Sonucunda Oluşan Faktör Sayısı ve Varyans Değerleri

\begin{tabular}{|c|c|c|c|c|c|c|c|c|c|}
\hline \multicolumn{4}{|c|}{ Özdeğer } & \multicolumn{3}{|c|}{ Faktör Yükleri Kareler Toplamı } & \multicolumn{3}{|c|}{$\begin{array}{c}\text { Döndürülmüş Faktör Yükleri } \\
\text { Kareler Toplamı }\end{array}$} \\
\hline Bileşen & Özdeğer & $\begin{array}{c}\text { Varyans } \\
\%\end{array}$ & $\begin{array}{c}\text { Toplam } \\
\text { Varyans } \\
\end{array}$ & Özdeğer & $\begin{array}{l}\text { Varyans } \\
\%\end{array}$ & $\begin{array}{c}\text { Toplam } \\
\text { Varyans } \\
\end{array}$ & Özdeğer & $\begin{array}{c}\text { Varyans } \\
\%\end{array}$ & $\begin{array}{l}\text { Toplam } \\
\text { Varyans } \\
\end{array}$ \\
\hline 1 & 16.754 & 30.462 & 30.462 & 16.754 & 30.462 & 30.462 & 11.393 & 20.714 & 20.714 \\
\hline 2 & 7.808 & 14.197 & 44.659 & 7.808 & 14.197 & 44.659 & 10.470 & 19.036 & 39.750 \\
\hline 3 & 2.838 & 5.160 & 49.819 & 2.838 & 5.160 & 49.819 & 2.815 & 5.119 & 44.868 \\
\hline 4 & 1.650 & 3.000 & 52.819 & 1.650 & 3.000 & 52.819 & 2.565 & 4.663 & 49.531 \\
\hline
\end{tabular}


Matematik Tarihi Destekli Matematik Derslerine Yönelik Motivasyon Ölçeğinin Geliştirilmesi: Geçerlik ve Güvenirlik Çalışması

\begin{tabular}{cccccccccc}
\hline 5 & 1.297 & 2.358 & 55.177 & 1.297 & 2.358 & 55.177 & 2.099 & 3.816 & 53.348 \\
6 & 1.251 & 2.274 & 57.451 & 1.251 & 2.274 & 57.451 & 1.479 & 2.689 & 56.037 \\
7 & 1.089 & 1.981 & 59.432 & 1.089 & 1.981 & 59.432 & 1.458 & 2.651 & 58.688 \\
8 & 1.011 & 1.838 & 61.269 & 1.011 & 1.838 & 61.269 & 1.420 & 2.581 & 61.269 \\
9 & .955 & 1.736 & 63.005 & & & & & & \\
10 & .869 & 1.581 & 64.586 & & & & & \\
\hline
\end{tabular}

Analiz sonucunda faktör yükleri arasında .1 den az fark olan ve birden fazla faktörde yükü olan binişik maddeler (m10, m76, m26, m12, m30, m56, m2), bir maddeden oluşan faktörlerdeki maddeler (m11), iki maddeden oluşan faktörlerdeki maddeler (m71, m69, m31, m61) çıkarılarak tekrar faktör analizi yapılmıştır.

Üçüncü faktör analizinde KMO değeri .955, Bartlett test sonucu ise anlamlı çıkmıştır. $(\chi 2=11132.141 ; \mathrm{p}<.05)$. Dolayısıyla veri seti faktör analizi için uygundur. Analiz sonucunda Tablo 5 'te görüldüğü üzere maddelerin özdeğeri 1'den büyük olan 4 faktör altında toplandığı ve açıklanan varyansın \%58.408 olduğu belirlenmiştir.

Tablo 5. Üçüncü Faktör Analizi Sonucunda Oluşan Faktör Sayısı ve Varyans Değerleri

\begin{tabular}{|c|c|c|c|c|c|c|c|c|c|}
\hline \multicolumn{4}{|c|}{ Özdeğer } & \multicolumn{3}{|c|}{ Faktör Yükleri Kareler Toplamı } & \multicolumn{3}{|c|}{$\begin{array}{c}\text { Döndürülmüş Faktör Yükleri } \\
\text { Kareler Toplamı }\end{array}$} \\
\hline Bileşen & Özdeğer & $\begin{array}{c}\text { Varyans } \\
\%\end{array}$ & $\begin{array}{l}\text { Toplam } \\
\text { Varyans } \\
\end{array}$ & Özdeğer & $\begin{array}{c}\text { Varyans } \\
\%\end{array}$ & $\begin{array}{l}\text { Toplam } \\
\text { Varyans } \\
\end{array}$ & Özdeğer & $\begin{array}{l}\text { Varyans } \\
\%\end{array}$ & $\begin{array}{l}\text { Toplam } \\
\text { Varyans } \\
\end{array}$ \\
\hline 1 & 14.841 & 34.514 & 34.514 & 14.841 & 34.514 & 34.514 & 10.662 & 24.795 & 24.795 \\
\hline 2 & 6.735 & 15.663 & 50.177 & 6.735 & 15.663 & 50.177 & 10.187 & 23.691 & 48.487 \\
\hline 3 & 2.487 & 5.785 & 55.962 & 2.487 & 5.785 & 55.962 & 2.952 & 6.866 & 55.353 \\
\hline 4 & 1.052 & 2.446 & 58.408 & 1.052 & 2.446 & 58.408 & 1.314 & 3.055 & 58.408 \\
\hline 5 & .960 & 2.233 & 60.641 & & & & & & \\
\hline
\end{tabular}

Faktör yükleri arasında .1'den az fark olan ve birden fazla faktörde yükü olan binişik maddeler (m34, m57, m93, m72), çıkarılarak tekrar faktör analizi yapılmıştır. Dördüncü faktör analizinde KMO değeri 0.955, Bartlett test sonucu ise anlamlı çıkmıştır. $(\chi 2=10137.289 ; \mathrm{p}<.05)$. Dolayısıyla veri seti faktör analizi için uygundur. Sonuç olarak Tablo 6'te görüldüğü üzere MTMMÖ’nün üç faktör ve 39 maddeden oluştuğu, bu maddelerin toplam varyansın \%57,41'ini açıkladığı görülmüştür. Açımlayıcı faktör analizinde açıklanan varyans oranı $\% 40$ ile $\% 60$ oranları arasında ise bu faktör yapısının güçlü olduğunu göstermektedir (Scherer, Wiebe, Luther \& Adams, 1988). MT-MMÖ’de yer alan maddelerin faktör yüklerine ve faktörlerin açıkladıkları varyans oranlarına dair bilgiler Tablo 6' da belirtilmiştir. 
Mersin \& Durmuş (2020)

Tablo 6. MT-MMÖ’nün Faktör Sayısını ve Açıklanan Varyans Oranına Ilişkin Tablo

\begin{tabular}{|c|c|c|c|c|c|c|c|c|c|}
\hline \multicolumn{4}{|c|}{ Özdeğer } & \multicolumn{3}{|c|}{ Faktör Yükleri Kareler Toplamı } & \multicolumn{3}{|c|}{$\begin{array}{c}\text { Döndürülmüş Faktör Yükleri } \\
\text { Kareler Toplamı }\end{array}$} \\
\hline Bileşen & Özdeğer & $\begin{array}{l}\text { Varyans } \\
\%\end{array}$ & $\begin{array}{l}\text { Toplam } \\
\text { Varyans }\end{array}$ & Özdeğer & $\begin{array}{c}\text { Varyans } \\
\%\end{array}$ & $\begin{array}{l}\text { Toplam } \\
\text { Varyans }\end{array}$ & Özdeğer & $\underset{\%}{\text { Varyans }}$ & $\begin{array}{l}\text { Toplam } \\
\text { Varyans }\end{array}$ \\
\hline 1 & 13.97 & 35.81 & 35.81 & 13.97 & 35.81 & 35.81 & 10.02 & 25.69 & 25.69 \\
\hline 2 & 6.30 & 16.16 & 51.96 & 6.30 & 16.16 & 51.96 & 9.64 & 24.73 & 50.42 \\
\hline 3 & 2.12 & 5.45 & 57.41 & 2.12 & 5.45 & 57.41 & 2.72 & 6.99 & 57.41 \\
\hline 4 & 0.93 & 2.39 & 59.80 & & & & & & \\
\hline 5 & 0.87 & 2.24 & 62.05 & & & & & & \\
\hline
\end{tabular}

Şekil 2'de ise 39 maddelik ölçeğin 3 faktör altında toplandığını gösteren yamaç birikinti grafiği verilmiştir. Şekil 2'ye göre grafiğin üçüncü faktöre kadar hızlı bir düşüş gösterdiği, dördüncü faktörden sonra ise yatay konumda olduğu görülmüştür. Buradan hareketle yamaç birikinti grafiğine göre de MT-MMÖ’nün üç faktörlü bir yapıdan oluştuğu söylenebilir.

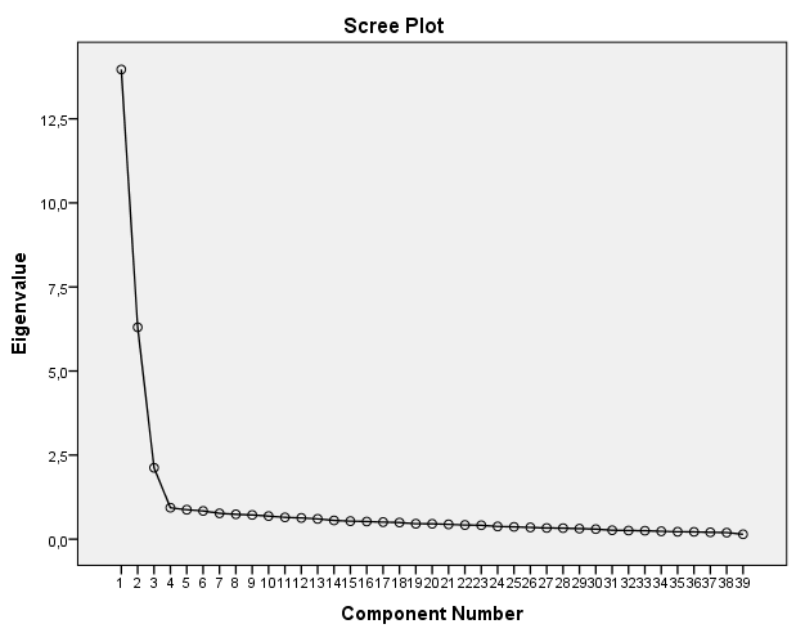

Şekil 2. Yamaç Birikinti Grafiği

Ölçek maddelerinin döndürülmüş madde yük değerleri, ortak varyansa katkıları Tablo 7'de verilmiştir.

Tablo 7. MT-MMÖ’ye ilişkin Faktör Analizi Sonuçları

\begin{tabular}{ccccc}
\hline Madde No & $\begin{array}{c}\text { Faktör Ortak } \\
\text { Varyans1 }\end{array}$ & \multicolumn{3}{c}{ Döndürülmüş Faktör Yük Değerleri } \\
\cline { 2 - 5 } m53 & & Faktör 1 & Faktör 2 & Faktör 3 \\
m49 & .68 & .81 & & \\
m36 & .66 & .77 & & \\
m54 & .61 & .76 & & \\
\hline
\end{tabular}


Matematik Tarihi Destekli Matematik Derslerine Yönelik Motivasyon Ölçeğinin Geliştirilmesi: Geçerlik ve Güvenirlik Çalışması

\begin{tabular}{|c|c|c|c|c|}
\hline & & & & \\
\hline $\mathrm{m} 38$ & .56 & .74 & & \\
\hline m52 & .56 & .73 & & \\
\hline m37 & .56 & .73 & & \\
\hline $\mathrm{m} 1$ & .55 & .73 & & \\
\hline $\mathrm{m} 25$ & .52 & .72 & & \\
\hline $\mathrm{m} 32$ & .52 & .70 & & \\
\hline $\mathrm{m} 48$ & .51 & .70 & & \\
\hline $\mathrm{m} 7$ & .49 & .70 & & \\
\hline m55 & .48 & .69 & & \\
\hline $\mathrm{m} 28$ & .47 & .68 & & \\
\hline m50 & .48 & .66 & & \\
\hline $\mathrm{m} 29$ & .48 & .66 & & \\
\hline $\mathrm{m} 18$ & .45 & .64 & & \\
\hline m33 & .48 & .64 & & \\
\hline $\mathrm{m} 23$ & .41 & .61 & & \\
\hline $\mathrm{m} 89$ & .73 & & .84 & \\
\hline $\mathrm{m} 90$ & .71 & & .82 & \\
\hline $\mathrm{m} 91$ & .70 & & .82 & \\
\hline m96 & .69 & & .82 & \\
\hline $\mathrm{m} 88$ & .69 & & .81 & \\
\hline m97 & .67 & & .79 & \\
\hline m92 & .65 & & .79 & \\
\hline m94 & .65 & & .78 & \\
\hline m87 & .63 & & .78 & \\
\hline $\mathrm{m} 86$ & .63 & & .76 & \\
\hline $\mathrm{m} 83$ & .60 & & .75 & \\
\hline $\mathrm{m} 98$ & .57 & & .74 & \\
\hline m95 & .59 & & .74 & \\
\hline $\mathrm{m} 84$ & .58 & & .70 & \\
\hline $\mathrm{m} 85$ & .56 & & .68 & \\
\hline $\mathrm{m} 73$ & .61 & & & .74 \\
\hline $\mathrm{m} 68$ & .55 & & & .72 \\
\hline $\mathrm{m} 74$ & .50 & & & .69 \\
\hline m63 & .55 & & & .68 \\
\hline m58 & .50 & & & .66 \\
\hline \multicolumn{2}{|c|}{ Öz değerler } & 13.97 & 6.30 & 2.124 \\
\hline \multirow{2}{*}{\multicolumn{2}{|c|}{$\begin{array}{l}\text { Açıklanan Varyans Oranı } \\
\text { Ackklanan Toplam Varvans }\end{array}$}} & $\% 25.69$ & $\% 24.73$ & $\% 6.99$ \\
\hline & & $\% 57.41$ & & \\
\hline
\end{tabular}

Tablo 7'ye göre birinci faktör 19 maddeden oluşmaktadır. Bu faktörün yük değerleri ise .61 ile .81 arasında, ikinci faktör 15 maddeden oluşmakta ve faktör yük değerleri .68 ile .84 arasında, üçüncü faktör 5 maddeden oluşmakta ve faktör yük değerleri .66 ile .74 arasında değişkenlik göstermektedir. Tabachnick ve Fidell (2001) maddelerin faktör yük değerlerinin .40'un üzerinde olan maddelerin çok iyi, .70 ve üstünde yer alan maddelerin ise mükemmel olduğu şeklinde değerlendirme yapmıştır. Dolayısıyla ölçekte yer alan maddelerin çok iyi ve mükemmel düzeyde olduğu söylenebilir. 


\section{MT-MMÖ’nün Faktörlerinin İsimlendirilmesi}

MT-MMÖ’yü oluşturan faktörler ölçeğin kuramsal çerçevesi ve başlangıçta oluşturulan faktör yapılarına uygun olarak dağıldığı için birinci faktör "matematik tarihi destekli matematik derslerine yönelik içsel motivasyon", ikinci faktör "matematik tarihi destekli matematik derslerine yönelik motivasyon yoksunluğu", üçüncü faktör ise "matematik tarihi destekli matematik derslerine yönelik dişsal motivasyon" şeklinde isimlendirilmiştir. Faktörlere yönelik örnek maddeler ise Tablo 8'de verilmiştir.

Tablo 8. MT-MMÖ’nün Faktörlerine Yönelik Örnek Maddeler

\begin{tabular}{cl}
\hline Faktör Adı & Örnek Maddeler \\
\hline \multirow{2}{*}{ İçsel } & MT destekli matematik dersleri matematiği benim için kolaylaştırır. \\
Motivasyon & MT destekli matematik derslerinde farklı yöntemler kullanıldı̆̆ için derslere katılmaya istekliyimdir. \\
& MT destekli matematik dersleri beni düşünmeye zorladığı için derslere katılmaya istekliyimdir. \\
\hline Dişsal & MT destekli matematik derslerine öğretmenimin beni takdir etmesi için katılırım. \\
Motivasyon & MT destekli matematik dersi ödevlerimi arkadaşlarımdan geride kalmak istemediğim için yaparım. \\
\hline & MT destekli matematik derslerindeki problem çözme yöntemleri ilgimi çekmediği için derse girmek \\
Motivasyon & istemem", \\
Yoksunluğu & "MT destekli matematik derslerini gereksiz gördüğüm için ilgimi çekmiyor \\
& MT destekli matematik derslerinin matematik notlarımı etkilemeyeceğini düşündüğüm için çalışmak \\
\hline
\end{tabular}

\section{Doğrulayıcı Faktör Analizi}

AFA ile elde edilen üç faktörlü MT-MMÖ’nün yapı geçerliliğini test etmek amacıyla birinci düzey DFA gerçekleştirilmiştir. DFA AMOS 6 programı kullanılarak gerçekleştirilmiştir. Buna göre DFA sonrasinda e35 ile e36, e21 ile e22, e27 ile e28, parametreleri arasinda modifikasyon yapıldığı takdirde kikare değerinin düşeceği ve modele katkı yapacağı görülmüştür. Bu nedenle bu parametreler arasına kovaryans eklenerek tekrar doğrulayıcı faktör analizi yapılmış ve modele son şekli verilmiştir. Tablo 9'da DFA sonucunda elde edilen ölçeğe ait uyum indeksi değerleri yer almaktadır. 
Matematik Tarihi Destekli Matematik Derslerine Yönelik Motivasyon Ölçeğinin Geliştirilmesi: Geçerlik ve Güvenirlik Çalışması

Tablo 9. DFA Sonucu Elde Edilen Uyum İndeksi Dĕ̌gerleri ve Karşılaştırılması

\begin{tabular}{|c|c|c|c|c|}
\hline $\begin{array}{l}\text { İncelenen } \\
\text { Uyum } \\
\text { İndeksleri }\end{array}$ & $\begin{array}{l}\text { Mükemmel Uyum } \\
\text { Ölçütleri }\end{array}$ & $\begin{array}{l}\text { Kabul Edilebilir Uyum } \\
\text { Ölçütleri }\end{array}$ & $\begin{array}{l}\text { Elde Edilen } \\
\text { Uyum } \\
\text { Indeksleri }\end{array}$ & Sonuç \\
\hline$\chi^{2 / s d}$ & $0 \leq \chi 2 / \mathrm{sd} \leq 2$ & $2 \leq \chi^{2 / s d} \leq 3$ & 1.86 & Mükemmel uyum \\
\hline GFI & $.90 \leq \mathrm{GFI} \leq 1.00$ & $.85 \leq \mathrm{GFI} \leq .90$ & .86 & Kabul edilebilir uyum \\
\hline AGFI & $.90 \leq \mathrm{AGFI} \leq 1.00$ & $.80 \leq \mathrm{AGFI} \leq .90$ & .84 & Kabul edilebilir uyum \\
\hline CFI & $.95 \leq \mathrm{CFI} \leq 1.00$ & $.90 \leq \mathrm{CFI} \leq .95$ & .94 & Kabul edilebilir uyum \\
\hline RMSEA & $.00 \leq$ RMSEA $\leq .05$ & $.05 \leq$ RMSEA $\leq .08$ & .046 & Mükemmel uyum \\
\hline SRMR & $.00 \leq \mathrm{SRMR} \leq .05$ & $.05 \leq \mathrm{SRMR} \leq .08$ & .05 & Mükemmel uyum \\
\hline
\end{tabular}

Tablo 9'a göre ki-kare uyum indeksi değerinin serbestlik derecesine oranı $(\chi 2 / \mathrm{sd}) 1.86$ olduğu, dolayısıyla mükemmel uyum ölçütlerini sağladığı görülmektedir. Nitekim bu değerin 0 ile 2 arasında olması mükemmel uyum olarak kabul edilmektedir (Bryne, 2010; Schermelleh-Engel ve diğerleri, 2003; Schumaker ve Lomax, 2004). GFI değerinin 0.85; AGFI değerinin ise .80 üzerinde olması kabul edilebilir uyum indeksleridir (Anderson \& Gerbing, 1984; Arbucle, 2007; Cole, 1987; Çam \& Günal, 2016; Çelik \& Turunç, 2011; Frias \& Dixon, 2005; Harrington, 2009; Jöreskog \& Sörbom, 1993; Kline, 1998; March, Balla \& McDonald, 1988; Marcholudis \& Schumacher, 2001; Tanaka \& Huba, 1985). Dolayısıyla DFA sonucunda .86 olan GFI ve .84 olan AGFI değerlerinin kabul edilebilir düzeyde olduğu söylenebilir. Buna ek olarak CFI değerinin .94 olması mükemmel uyumun olduğunu göstermektedir (Hu ve Bentler, 2000; Sümer, 2000; Şimşek, 2007; Yılmaz ve Çelik, 2009). Yaklaşık hataların ortalama karekökünü gösteren RMSEA değerinin .046 olması ise modelin mükemmel uyumunu belirtmektedir (Bryne, 2010; SchermellehEngel ve diğg., 2003; Schumaker \& Lomax, 2004). Bu durumda ölçeğe ait modelin iyi uyum gösterdiği söylenebilir. SRMR değeri .05 çıkmış ve bu değer .05'e eşit veya küçük olması model ve verinin güçlü bir uyum içinde olduğunu göstermektedir. (Brown, 2006; Byrne, 1994). Ölçeğe ait diğer değerlere bakıldığında IFI .94, PNFI .82 bulunmuştur. Bu değerler ise Marsh ve Hau (1996) ya göre iyi uyum göstergesidir. DFA'dan elde edilen verilere göre MT-MMÖ’nün iyi uyum 
gösteren bir modele sahip olduğu söylenebilir. Şekil 3'te MT-MMÖ’nün birinci düzey DFA sonucu oluşan path diyagramı yer almaktır.

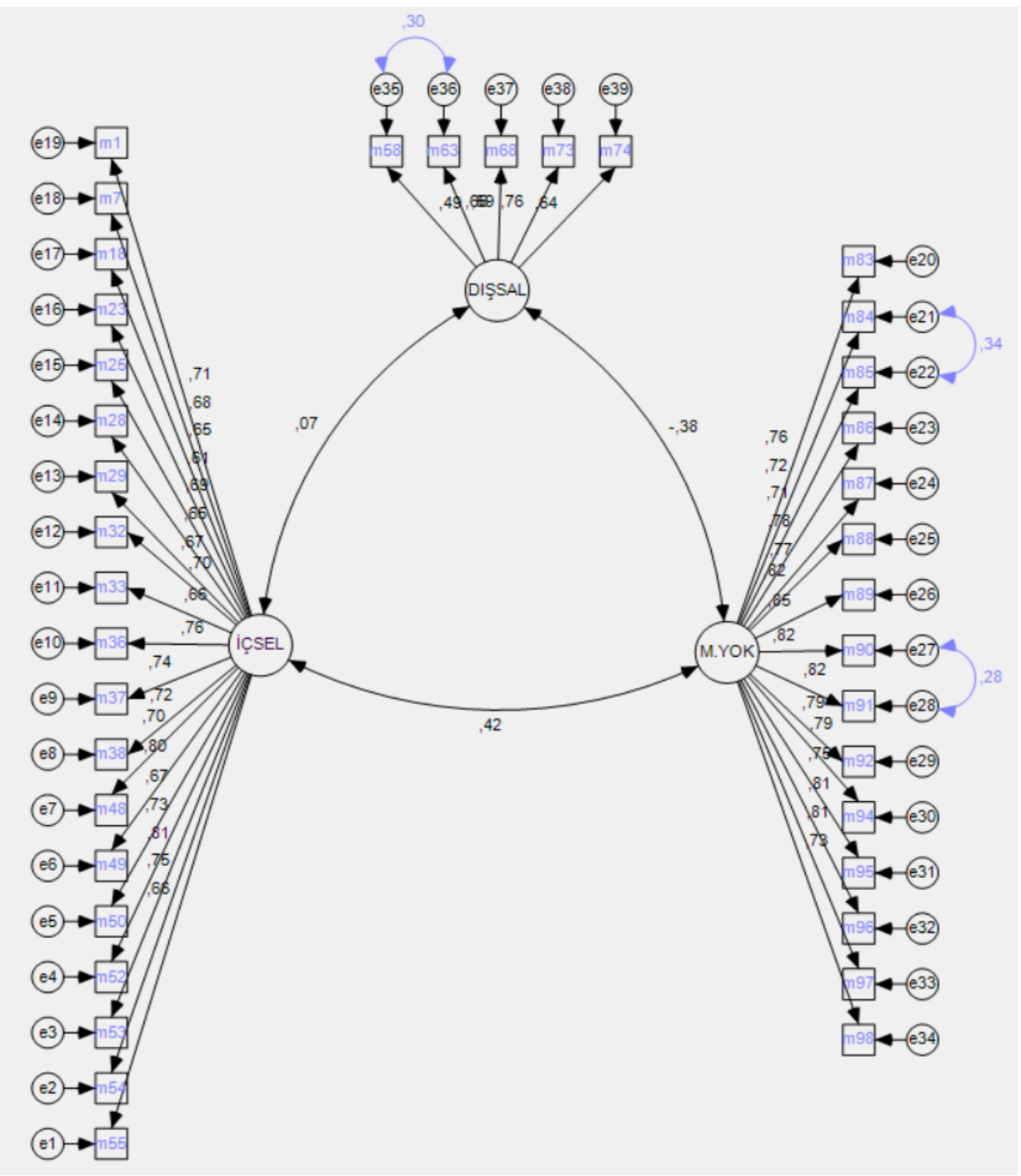

Şekil 3. MT-MMÖ’nün Birinci Düzey Faktör Analizine Dair Path Diyagramı

\section{MT-MMÖ için Güvenirlik ve Madde Analizi}

MT-MMÖ’nün tamamının ve faktörlerinin iç tutarlıkları Cronbach Alpha katsayısı ile hesaplanmıştır. Bununla birlikte ölçekteki maddelerin ölçülmek istenen motivasyon özelliğini ölçüp ölçmediğini belirlemek için madde- toplam korelasyon değerleri incelenmiştir. Dolayısıyla MT-MMÖ’nün ve faktörlerinin güvenirlik değerleri Tablo 10'da verilmiştir. 
Matematik Tarihi Destekli Matematik Derslerine Yönelik Motivasyon Ölçeğinin Geliştirilmesi: Geçerlik ve Güvenirlik Çalışması

Tablo 10. MT-MMÖ’ye Yönelik Güvenirlik Katsayıları

\begin{tabular}{lc}
\hline & Güvenirlik \\
İçsel Motivasyon & .95 \\
Motivasyon Yoksunluğu & .96 \\
Dişsal Motivasyon & .78 \\
Tüm Ölçek & .93 \\
\hline
\end{tabular}

Tablo 10’a göre ölçeğin bütününe ait güvenirlik değeri 932 olarak hesaplanırken, MT destekli matematik derslerine yönelik içsel motivasyon faktörünün güvenirlik katsayısı .95, MT destekli matematik derslerine yönelik motivasyon yoksunluğu faktörünün güvenirlik katsayısı .96 ve MT destekli matematik derslerine yönelik dişsal motivasyon faktörünün katsayısı .78 olarak hesaplanmıştır. Güvenirlik katsayısının .70 ve üstünde olması yeterli görülmüş ve bu değer 1'e yaklaştıkça ölçeğin yüksek iç güvenirliğe sahip olacağı belirtilmiştir (Büyüköztürk, 2007; Fraenkel ve Wallen, 2006). Dolayısıyla geliştirilen ölçeğin yüksek düzeyde güvenilir olduğu söylenebilir.

Tablo 11. Madde Ortalama, Standart Sapma, Madde Toplam Korelasyonlarl ve Madde Çıkarıldı̆̆ııda Cronbach Alfa Katsayısı

\begin{tabular}{|c|c|c|c|c|}
\hline Maddeler & $\bar{x}$ & SS & $\begin{array}{l}\text { Madde Toplam } \\
\text { Korelasyonu }\end{array}$ & $\begin{array}{l}\text { Madde Çıkarıldığında } \\
\alpha \text { katsayısı }\end{array}$ \\
\hline \multicolumn{5}{|c|}{ Faktör 1: İçsel Motivasyon $(\alpha=.95)$} \\
\hline m53 & 3.80 & 1.227 & .789 & .944 \\
\hline $\mathrm{m} 49$ & 3.89 & 1.187 & .778 & .944 \\
\hline $\mathrm{m} 36$ & 3.88 & 1.160 & .740 & .945 \\
\hline m54 & 3.78 & 1.251 & .722 & .945 \\
\hline $\mathrm{m} 38$ & 3.64 & 1.209 & .705 & .945 \\
\hline m52 & 3.84 & 1.162 & .707 & .945 \\
\hline $\mathrm{m} 37$ & 3.85 & 1.140 & .711 & .945 \\
\hline $\mathrm{m} 1$ & 3.82 & 1.084 & .702 & .945 \\
\hline $\mathrm{m} 25$ & 3.44 & 1.197 & .673 & .946 \\
\hline m32 & 3.93 & 1.105 & .681 & .946 \\
\hline $\mathrm{m} 48$ & 3.93 & 1.159 & .673 & .946 \\
\hline $\mathrm{m} 7$ & 3.77 & 1.143 & .656 & .946 \\
\hline m55 & 3.67 & 1.329 & .646 & .946 \\
\hline $\mathrm{m} 28$ & 3.78 & 1.190 & 639 & .946 \\
\hline $\mathrm{m} 50$ & 3.92 & 1.195 & .650 & .946 \\
\hline $\mathrm{m} 29$ & 3.82 & 1.254 & .651 & .946 \\
\hline $\mathrm{m} 18$ & 3.87 & 1.121 & .632 & .946 \\
\hline $\mathrm{m} 33$ & 4.11 & 1.122 & .641 & .946 \\
\hline $\mathrm{m} 23$ & 3.63 & 1.306 & .589 & .947 \\
\hline \multicolumn{5}{|c|}{ Faktör 2: D1şsal Motivasyon $(\alpha=.78)$} \\
\hline $\mathrm{m} 73$ & 2.98 & 1.403 & .607 & .716 \\
\hline m68 & 2.89 & 1.363 & .549 & .735 \\
\hline $\mathrm{m} 74$ & 2.93 & 1.450 & .529 & .742 \\
\hline m63 & 3.32 & 1.455 & .569 & .728 \\
\hline m58 & 3.06 & 1.527 & .497 & .754 \\
\hline
\end{tabular}


Mersin \& Durmuş (2020)

\begin{tabular}{|c|c|c|c|c|}
\hline \multicolumn{5}{|c|}{ Fakör 3: Motivasyon yoksunluğu $(\alpha=.96)$} \\
\hline m89 & 4.20 & 1.194 & .825 & .955 \\
\hline $\mathrm{m} 90$ & 4.15 & 1.241 & .812 & .956 \\
\hline m91 & 4.13 & 1.256 & .809 & .956 \\
\hline m96 & 4.17 & 1.235 & .794 & .956 \\
\hline $\mathrm{m} 88$ & 4.17 & 1.199 & .801 & .956 \\
\hline m97 & 4.21 & 1.214 & .784 & .956 \\
\hline m92 & 4.00 & 1.298 & .772 & .956 \\
\hline m94 & 4.12 & 1.222 & .768 & .957 \\
\hline m87 & 4.16 & 1.255 & .756 & .957 \\
\hline $\mathrm{m} 86$ & 4.05 & 1.299 & .762 & 957 \\
\hline $\mathrm{m} 83$ & 4.07 & 1.345 & .738 & .957 \\
\hline m98 & 4.09 & 1.284 & .713 & .958 \\
\hline m95 & 4.12 & 1.206 & .728 & .957 \\
\hline m84 & 3.95 & 1.328 & .722 & .958 \\
\hline $\mathrm{m} 85$ & 3.90 & 1.307 & .709 & .958 \\
\hline
\end{tabular}

Tablo 11'e göre MT destekli matematik derslerine yönelik içsel motivasyon faktöründe maddelerin madde toplam korelasyon değerlerinin .589 ve .789; MT destekli matematik derslerine yönelik dişsal motivasyon faktöründe .497 ve .607; MT destekli matematik derslerine yönelik motivasyon yoksunluğu faktöründe .709 ve .825 arasında değiştiği görülmektedir. Bu değerlerin 0.30’un üzerinde olması maddelerin yüksek iç tutarlığa ve ayırt ediciliğe sahip ve ölçme amacına uygun olduklarını göstermektedir (Büyüköztürk, 2007). Ayrıca ölçekte yer alan maddelerin çıkarıldığında güvenirlik değerleri yükselmediği belirlenmiştir. Ölçekte yer alan maddelerin alt ve üst grupları yeterince ayırt edip etmediğini belirlemek amacıyla $\% 27$ 'lik alt ve üst grupların puanlarına ilişkisiz örneklemler $t$ testi yapılmıştır. Analiz sonuçlarını veren Tablo 12 incelendiğinde her maddenin alt ve üst grupları birbirinden anlamlı bir şekilde ayırt edebildiği görülmektedir ( $<$ <.00). Buradan hareketle MT-MMÖ’nün yüksek motivasyona sahip öğrenciler ile düşük motivasyona sahip olan öğrencileri ayırt edebildiği, dolayısıyla ölçeğin de yüksek iç tutarlığa sahip olduğu söylenebilir.

Tablo 12. MT-MMÖ’nün Maddelerine Yönelik Alt-Üst \%27’lik Gruplar için İlişkisiz Örneklemler T Testi Sonuçları

\begin{tabular}{|c|c|c|c|c|c|c|c|}
\hline Maddeler & Grup & $\mathrm{N}$ & $\bar{X}$ & $\mathrm{~S}$ & df & $\mathrm{t}$ & $\mathrm{p}$ \\
\hline \multirow[t]{2}{*}{$\mathrm{m} 7$} & Üst & 107 & 4.5421 & .70417 & 212 & \multirow{2}{*}{10.773} & \multirow[t]{2}{*}{.000} \\
\hline & Alt & 107 & 3.1028 & 1.18906 & 212 & & \\
\hline \multirow[t]{2}{*}{$\mathrm{m} 1$} & Üst & 107 & 4.5981 & .65675 & 212 & \multirow{2}{*}{11.460} & \multirow[t]{2}{*}{.000} \\
\hline & Alt & 107 & 3.0841 & 1.19844 & 212 & & \\
\hline \multirow[t]{2}{*}{$\mathrm{m} 18$} & Üst & 107 & 4.6636 & .64346 & 212 & \multirow{2}{*}{11.890} & \multirow[t]{2}{*}{.000} \\
\hline & Alt & 107 & 3.0841 & 1.21408 & 212 & & \\
\hline \multirow[t]{2}{*}{$\mathrm{m} 23$} & Üst & 107 & 4.4019 & .87803 & 212 & \multirow{2}{*}{9.152} & \multirow[t]{2}{*}{.000} \\
\hline & Alt & 107 & 2.9065 & 1.44413 & 212 & & \\
\hline \multirow[t]{2}{*}{$\mathrm{m} 25$} & Üst & 107 & 4.2150 & .85812 & 212 & \multirow{2}{*}{10.202} & \multirow[t]{2}{*}{.000} \\
\hline & Alt & 107 & 2.6916 & 1.28424 & 212 & & \\
\hline $\mathrm{m} 28$ & Üst & 107 & 4.6262 & .63726 & 212 & 10.696 & .000 \\
\hline
\end{tabular}


Matematik Tarihi Destekli Matematik Derslerine Yönelik Motivasyon Ölçeğinin Geliştirilmesi: Geçerlik ve Güvenirlik Çalışması

\begin{tabular}{|c|c|c|c|c|c|c|c|}
\hline & Alt & 107 & 3.1215 & 1.30825 & 212 & & \\
\hline \multirow[t]{2}{*}{$\mathrm{m} 29$} & Üst & 107 & 4.7570 & .51103 & 212 & \multirow{2}{*}{13.680} & \multirow[t]{2}{*}{.000} \\
\hline & Alt & 107 & 2.8318 & 1.36317 & 212 & & \\
\hline \multirow[t]{2}{*}{ m32 } & Üst & 107 & 4.7757 & .50110 & 212 & \multirow{2}{*}{12.456} & \multirow[t]{2}{*}{.000} \\
\hline & Alt & 107 & 3.1215 & 1.27908 & 212 & & \\
\hline \multirow[t]{2}{*}{ m33 } & Üst & 107 & 4.8318 & .52280 & 212 & \multirow{2}{*}{11.026} & \multirow[t]{2}{*}{.000} \\
\hline & Alt & 107 & 3.2804 & 1.35837 & 212 & & \\
\hline \multirow[t]{2}{*}{ m36 } & Üst & 107 & 4.6542 & .55120 & 212 & \multirow{2}{*}{11.859} & \multirow[t]{2}{*}{.000} \\
\hline & Alt & 107 & 2.9907 & 1.34231 & 212 & & \\
\hline \multirow[t]{2}{*}{ m37 } & Üst & 107 & 4.6729 & .50982 & 212 & \multirow{2}{*}{12.251} & \multirow[t]{2}{*}{.000} \\
\hline & Alt & 107 & 3.0280 & 1.29190 & 212 & & \\
\hline \multirow[t]{2}{*}{$\mathrm{m} 38$} & Üst & 107 & 4.4953 & .66409 & 212 & 11397 & .000 \\
\hline & Alt & 107 & 2.8692 & 1.31812 & 212 & 11.591 & \\
\hline $\mathrm{m} 48$ & Üst & 107 & 4.7850 & .47639 & 212 & 11384 & .000 \\
\hline & Alt & 107 & 3.1963 & 1.36284 & 212 & 11.384 & \\
\hline $\mathrm{m} 49$ & Üst & 107 & 4.8692 & .36560 & 212 & & .000 \\
\hline & Alt & 107 & 2.9065 & 1.28513 & 212 & 15.194 & \\
\hline $\mathrm{m} 50$ & Üst & 107 & 4.7850 & .47639 & 212 & 12115 & .000 \\
\hline & Alt & 107 & 3.0935 & 1.36349 & 212 & 12.115 & \\
\hline m52 & Üst & 107 & 4.7009 & .68975 & 212 & 10989 & .000 \\
\hline & Alt & 107 & 3.1121 & 1.32698 & 212 & 10.909 & \\
\hline m53 & Üst & 107 & 4.8224 & .40778 & 212 & & .000 \\
\hline & Alt & 107 & 2.8505 & 1.33744 & 212 & 14.589 & \\
\hline m54 & Üst & 107 & 4.6636 & .65795 & 212 & & .000 \\
\hline & Alt & 107 & 2.8785 & 1.39886 & 212 & 11.945 & \\
\hline m55 & Üst & 107 & 4.6449 & .70379 & 212 & 10826 & .000 \\
\hline & Alt & 107 & 2.9346 & 1.47476 & 212 & 10.820 & \\
\hline m58 & Üst & 107 & 4.1121 & 1.31986 & 212 & 9325 & .000 \\
\hline & Alt & 107 & 2.4393 & 1.30440 & 212 & 9.325 & \\
\hline $\mathrm{m} 63$ & Üst & 107 & 4.2617 & 1.24640 & 212 & & .000 \\
\hline & Alt & 107 & 2.6822 & 1.31464 & 212 & 9.019 & \\
\hline m68 & Üst & 107 & 3.4393 & 1.40872 & 212 & & .000 \\
\hline & Alt & 107 & 2.7850 & 1.28876 & 212 & 3.544 & \\
\hline m73 & Üst & 107 & 3.6542 & 1.36743 & 212 & 5100 & .000 \\
\hline & Alt & 107 & 2.7103 & 1.33889 & 212 & 5.102 & \\
\hline $\mathrm{m} 74$ & Üst & 107 & 3.5607 & 1.47416 & 212 & & .000 \\
\hline & Alt & 107 & 2.7757 & 1.33394 & 212 & 4.085 & \\
\hline $\mathrm{m} 83$ & Üst & 107 & 4.9252 & .42783 & 212 & 16340 & .000 \\
\hline & Alt & 107 & 2.6636 & 1.36633 & 212 & 10.340 & \\
\hline $\mathrm{m} 84$ & Üst & 107 & 4.8879 & .50145 & 212 & 16409 & .000 \\
\hline & Alt & 107 & 2.7477 & 1.24456 & 212 & 10.499 & \\
\hline $\mathrm{m} 85$ & Üst & 107 & 4.8972 & .33462 & 212 & 17517 & .000 \\
\hline & Alt & 107 & 2.7009 & 1.25303 & 212 & 17.311 & \\
\hline $\mathrm{m} 86$ & Üst & 107 & 4.9907 & .09667 & 212 & & .000 \\
\hline & Alt & 107 & 2.7477 & 1.32532 & 212 & 17.460 & \\
\hline $\mathrm{m} 87$ & Üst & 107 & 5.0000 & .00000 & 212 & & .000 \\
\hline & Alt & 107 & 2.8879 & 1.33408 & 212 & $16.3 / 1$ & \\
\hline $\mathrm{m} 88$ & Üst & 107 & 5.0000 & .00000 & 212 & 17078 & .000 \\
\hline & Alt & 107 & 2.9252 & 1.25669 & 212 & 17.070 & \\
\hline m89 & Üst & 107 & 4.9533 & .28758 & 212 & & .000 \\
\hline & Alt & 107 & 2.9065 & 1.30697 & 212 & 15.821 & \\
\hline $\mathrm{m} 90$ & Üst & 107 & 4.9813 & .19335 & 212 & & .000 \\
\hline & Alt & 107 & 2.8318 & 1.34225 & 212 & 16.396 & \\
\hline m91 & Üst & 107 & 4.9720 & .21535 & 212 & 17766 & .000 \\
\hline & Alt & 107 & 2.7944 & 1.24944 & 212 & 17.100 & \\
\hline $\mathrm{m} 92$ & Üst & 107 & 4.8785 & .44953 & 212 & & .000 \\
\hline & Alt & 107 & 2.7196 & 1.22701 & 212 & 17.089 & \\
\hline m94 & Üst & 107 & 4.9907 & .09667 & 212 & 17.368 & .000 \\
\hline
\end{tabular}


Mersin \& Durmuş (2020)

\begin{tabular}{|c|c|c|c|c|c|c|c|}
\hline & Alt & 107 & 2.9252 & 1.22629 & 212 & & \\
\hline \multirow[t]{2}{*}{$\mathrm{m} 95$} & Üst & 107 & 4.8879 & .48227 & 212 & \multirow{2}{*}{15.278} & \multirow[t]{2}{*}{.000} \\
\hline & Alt & 107 & 2.9813 & 1.19733 & 212 & & \\
\hline \multirow[t]{2}{*}{ m96 } & Üst & 107 & 4.9533 & .21205 & 212 & \multirow{2}{*}{17.576} & \multirow[t]{2}{*}{.000} \\
\hline & Alt & 107 & 2.8037 & 1.24718 & 212 & & \\
\hline \multirow[t]{2}{*}{ m97 } & Üst & 107 & 4.9907 & .09667 & 212 & \multirow{2}{*}{16.802} & \multirow[t]{2}{*}{.000} \\
\hline & Alt & 107 & 2.8879 & 1.29095 & 212 & & \\
\hline \multirow[t]{2}{*}{ m98 } & Üst & 107 & 4.9065 & .40124 & 212 & \multirow{2}{*}{16.140} & \multirow[t]{2}{*}{.000} \\
\hline & Alt & 107 & 2.7757 & 1.30535 & 212 & & \\
\hline
\end{tabular}

\section{Sonuç Tartışma ve Öneriler}

$\mathrm{Bu}$ çalışmada ortaokul öğrencilerinin $(5,6,7,8$. sınıf) MT destekli matematik derslerine yönelik motivasyonu ölçmek amacıyla 39 madde (24 olumlu, 15 olumsuz) ve üç faktörden oluşan bir ölçek geliştirilmesi amaçlanmıştır. Bu doğrultuda 397 öğrenciden toplanan verilere öncelikle AFA uygulanmıştır. AFA sonrasında ölçeğin faktörleri toplam varyansın yaklaşık \% 57'sini açıklamıştır. İçsel motivasyon faktöründe 19, dişsal motivasyon faktöründe 5, motivasyon yoksunluğu faktöründe ise 15 madde yer almıştır. MT-MMÖ’nün yapı geçerliliğini test etmek amaciyla AFA'dan sonra DFA uygulanmıştır. DFA sonrasında modelin iyi uyum değerlerine sahip olduğu görülmüştür. Ayrıca MT-MMÖ’de yer alan maddelerin ölçülmenin istendiği hedef özellikleri ölçüp ölçmediğini belirlemek amacıyla madde-toplam korelasyon değerlerine bakılmıştır. Bu değerlerin .3'ün üzerinde olduğu, bu sebeple MT-MMÖ’nün ölçme amacına uygun olduğu söylenebilir. MT-MMÖ’nün \%27'lik alt ve üst gruplar arasında yapılan ilişkisiz örneklemler t testi sonuçlarına göre ise tüm maddelerin alt ve üst grupları anlamlı derecede ayırdığı sonucuna ulaşılmıştır. Elde edilen sonuçlara göre ölçeğin geçerli olduğu görülmüştür. Güvenirliliğini araştırmak amacıyla hesaplanan Cronbach-Alfa güvenirlik katsayısı ölçeğin tümü için .93, içsel motivasyon için .95, dişsal motivasyon için .78, motivasyon yoksunluğu için ise 96 olarak hesaplanmıştır. Bu değerler ölçeğin yüksek düzeyde güvenirliğe sahip olduğunu göstermektedir. Bununla birlikte örneklem seçiminde uygun örnekleme yönteminin kullanılması bu araştırmanın bir sınırlılığı olarak görülebilir. Nitekim daha geniş bir örneklemin ve evreni daha fazla temsil edecek şekilde bir örnekleme yönteminin kullanıldığı bir uygulama daha verimli sonuçlara ulaşma açısından etkili olabilir.

MT-MMÖ 5'li likert türünde olup 1: Kesinlikle Katılmıyorum, 2: Katılmıyorum, 3: Kararsızım, 4: Katılıyorum, 5: Kesinlikle Katılıyorum şeklindedir. MT-MMÖ’de yer alan olumlu 
Matematik Tarihi Destekli Matematik Derslerine Yönelik Motivasyon Ölçeğinin Geliştirilmesi: Geçerlik ve Güvenirlik Çalışması maddeler 5'ten 1'e doğru, olumsuz maddeler ise 1'den 5'e doğru olacak şekilde puanlanmıştır. Ölçekten alınabilecek maksimum puan 195, minimum puan ise 39'dur.

MT-MMÖ’nün on dokuz maddeden oluşan ilk faktörü öğrencilerin MT destekli matematik derslerine yönelik içsel motivasyonlarını ölçmeyi hedeflemiştir. İçsel motivasyon faktörü, öğrencilerin MT destekli matematik derslerine yönelik içsel kaynaklı bilme, yeterli olma, merak etme, öğrenme sonucunda oluşan haz ve doyum olgusunu ölçmeyi amaçlamaktadır (Akbaba, 2006; Vallerand \& Senecal, 1992). Bu faktörden alınabilecek minimum puan 19 iken maksimum puan 95'tir. Buradan hareketle bu faktörden yüksek puan alan öğrencilerin MT destekli matematik derslerine yönelik içsel motivasyonlarının yüksek olduğu, dolayısıyla MT’nin matematik derslerinde yer almasının, öğrencilerin öğrenmelerini olumlu katkı sağlayabileceği söylenebilir.

Dişsal motivasyon faktörü beş maddeden oluşmuştur ve alınabilecek en düşük puan 5 iken, en yüksek puan 25'tir. Bu faktörden yüksek puan alan öğrenciler, genellikle öğretmenlerinin, arkadaşlarının veya ebeveynlerinin karşısında olumlu bir profil çizmek istemekte, düşük not almamak, takdir kazanmak veya cezalardan kaçınmak için derse yönelik dişsal motivasyon sergilemektedirler (Ayık, Ataş Akdemir \& Seçer, 2015; Duda \& Nicholls, 1992; Middleton \& Spanias, 1999). İçsel motivasyon ve dişsal motivasyon karşılaştırıldığında öğrencilerin öğrenmelerini içsel motivasyonun daha derinden etkilediği bilinmektedir. Ancak her öğrencinin her ders için içsel motivasyona sahip olamayacağı da bir gerçek olarak karşımıza çıkmaktadır. Bu durumda dışsal motivasyonun öğrencilerin içsel motivasyon kazanmasında aracılık etmesi önemli görülmektedir (Akbaba, 2006).

MT-MMÖ’nün son faktörü olan ise MT destekli matematik derslerine yönelik motivasyon yoksunluğu, içsel ya da dışsal motivasyona sahip olunmadığını gösteren davranış veya etkinliklere değer vermeme veya MT destekli matematik derslerine ilişkin kendini yetersiz hissederek, istediğini elde edemeyeceğini düşündüklerini ifade eden maddelerden oluşmaktadır (Deci ve Ryan, 2000). Bu faktör 12 maddeden oluşmakta ve alınabilecek en düşük puan 12 iken en yüksek puan 60’tır. Bu faktörden yüksek puan alan öğrencilerin matematik tarihi destekli matematik derslerine yönelik motivasyon yoksunluğu yaşadığı söylenebilir.

MT, ortaokul matematik dersleri için hazine değerinde kaynaklar \& sunmaktadır. Öğrencilerin matematik öğrenmelerini kolaylaştırmak ve derse yönelik motivasyonlarını sağlamak amacıyla bu kaynaklardan yararlanmanın önemli olduğu düşünülmektedir. Elbette ki her öğrencinin motivasyon kaynağı farklılık gösterebilir. Ancak öğretmenlerin, MT’nin öğrenciler için 
motivasyon kaynağı olup olmadığını belirleyerek, derslerini bu duruma göre şekillendirmeleri, öğrencilerin matematik öğrenmelerini kolaylaştırma ve matematik başarılarını arttırma adına önemli bir adım olarak görülmektedir. Bu anlamda geliştirilen MT-MMÖ’nün alana özgün katkılar sunacağı düşünülmektedir.

Etik Kurul İzin Bilgisi: Bu araştırma Abant İzet Baysal Üniversitesi Sosyal Bilimlerde Insan Araştırmaları Etik Kurulunun 02/01/2018 tarihli 2018/01sayılı kararı ile alınan izinle yürütülmüştür.

\section{Yazar Katkı Beyanı:}

1. Nazan MERSíN: Ölçek maddeleri için literatür tarama, maddeleri yazma, uzman görüşü alma, uygulama yapma, analizleri yapma, yazma.

2. Soner DURMUŞ: danışmanlık ve denetim (ölçme aracı, veri analizi). inceleme-yazma ve düzenleme

\section{Kaynakça}

Açıkgöz, K. Ü. (2003). Etkili öğrenme ve ögretme. Eğitim Dünyası Yayınları.

Akbaba, S. (2006). Eğitimde motivasyon. Atatürk Üniversitesi Kazım Karabekir Eğitim Fakültesi Dergisi, (13), 343-361.

Akçakın, V. (2018). Matematik öğrenmeye yönelik motivasyon ölçeğinin Türkçe formunun geçerlik ve güvenirlik çalışması. Afyon Kocatepe Üniversitesi Sosyal Bilimler Dergisi, 20(1), 259-277.

Aktan, S., \& Tezci, E. (2013). Matematik motivasyon ölçeği (MMÖ) geçerlik ve güvenirlik çalışması. International Journal of Social Science, 6(4), 57-77.

Alkan, V. (2010). Matematikten nefret ediyorum!. Pamukkale Üniversitesi Eğitim Fakültesi Dergisi, 28(28), 189-199.

Alpaslan, M., Isiksal, M., \& Haser, C. (2011). The development of attitudes and beliefs questionnaire towards using history of mathematics in mathematics education. In Proceedings of the seventh congress of the European society for research in mathematics education (pp. 1661-1669). Rzesow, Poland: Universityof Rzeszow. 
Matematik Tarihi Destekli Matematik Derslerine Yönelik Motivasyon Ölçeğinin Geliştirilmesi: Geçerlik ve Güvenirlik Çalışması

Anderson, J. C., \& Gerbing, D. W. (1984). The effect of sampling error on convergence, improper solutions, and goodness-of-fit indices for maximum likelihood confirmatory factor analysis. Psychometrika, 49(2), 155-173.

Arbuckle, J. L. (2007). AMOS 16.0. Spring House, PA: Amos Development Corporation.

Arcavi, A. \& Isoda, M. (2007). Learning to listen: From historical sources to classroom practice. Educational Studies in Mathematics, 66(2), 111-129.

Ayık, A., Ataş Akdemir, Ö. \& Seçer, İ. (2015). Öğretme motivasyonu ölçeğinin Türkçe’ye uyarlanması: Geçerlik ve güvenirlik çalışması. Current Research in Education, 1(1), 3345.

Aytaçlı, B., \& Gündoğdu, K. (2019). Matematik uygulamaları dersi değer algısı ölçeği geçerlik ve güvenirlik çalışması. Gazi University Journal of Gazi Educational Faculty (GUJGEF), 39(1), 171-191.

Bacanl1, H., \& Sahinkaya, O., 2011. The adaptation study of academic motivation scale intoTurkish. Procedia Soc. Behav. Sci. 12, 562-567

Balantekin, Y., \& Bilgin, A. (2017). ARCS Motivasyon modeli’nin öğrencilerin motivasyonlarına, tutumlarına ve akademik başarılarına etkisi. Elementary Education Online, 16(1), 161-177.

Balantekin, Y., \& Oksal, A. (2014). İlkokul 3. ve 4. sınıf öğrencileri için matematik dersi motivasyon ölçeği. Cumhuriyet International Journal of Education-CIJE, 3(2), 102-113.

Başıbüyük, K., \& Sahin, Ö. (2019). Mathematics teachers' opinion about the history of mathematics. Acta Didactica Napocensia, 12(2), 117-132.

Baykul, Y. (2009). Illkögretimde matematik öğretimi 6-8. sinıflar. Ankara: Pegem Akademi Yayınc1lik.

Bruinsma, M. (2003) Leidt hogere motivatie tot betere prestaties? Motivatie, informatieverwerking en studievoortgang in het hoger onderwijs. [Does higher motivation result in higher achievement? Motivation, cognitive processing and achievement in higher education]. Pedagogische Studiën 80, 226- 238. 
Mersin \& Durmuş (2020)

Burns, B. A. (2010). Pre-Service teachers' exposure to using the history of mathematics to enhance their teaching of high school mathematics. Issues in the Undergraduate Mathematics Preparation of School Teachers, 4.

Bütüner, S. Ö. (2016). The use of concrete learning objects taken from the history of mathematics in mathematics education. International Journal of Mathematical Education in Science and Technology, 47(8), 1156-1178.

Bütüner, S. Ö. (2018). Secondary school mathematics teachers' knowledge levels and use of history of mathematics. Journal of Education and Training Studies, 6(1), 9-20.

Bütüner, S. Ö., \& Adnan, Baki, A. (2011). Matematik tarihinin kullanımına yönelik tutum ölçeğinin geliştirilmesi. Necatibey Eğitim Fakültesi Elektronik Fen ve Matematik Ĕ̆itimi Dergisi, 5(2), 278-311.

Büyükköztürk, S. (2007). Sosyal bilimler için veri analizi el kitabı. Ankara: Pegem A Yayıncılık.

Byrne, B. M. (2010). Structural Equation Modeling with AMOS: basic concepts, applications, and programming (2nd ed.). New York: Taylor and Francis Group, LLC.

Çakmak, M., \& Ercan, L. (2006). Etkili öğretim sürecinde deneyimli öğretmenler ve öğretmen adaylarının motivasyon konusunda görüşleri. Gazi Eğitim Fakültesi Dergisi, 26(3).

Çam, H. \& Günal, Z. (2016). İşletmelerin dış kaynak kullanımını etkileyen faktörlerin yapısal eşitlik modeli yaklaşımı ile belirlenmesi. Gümüşhane Üniversitesi Sosyal Bilimler Enstitüsü Elektronik Dergisi, 7(15), 210-229.

Carter, M. D. (2006). The role of the history of mathematics in middle school. Unpublished masters thesis. East Tennessee State University, USA.

Çelik, M., \& Turunç, Ö. (2011). Duygusal emek ve psikolojik sıkıntı: iş-aile çatışmasının aracılık etkisi. Istanbul University Journal of the School of Business Administration, 40(2).

Çokluk, Ö., Şekercioğlu, G., \& Büyüköztürk, Ş. (2012). Sosyal Bilimler için çok değişkenli istatistik SPSS ve LISREL uygulamaları (2.Bask1). Ankara: Pegem Akademi.

Cole, D. A. (1987). Utility of confirmatory factor analysis in test validation research. Journal of consulting and clinical psychology, 55(4), 584.

Comrey, A. L., \& Lee, H. B. (1992). Interpretation and application of factor analytic results. Comrey AL, Lee HB. A first course in factor analysis, 2, 1992.

Deci, E. L., \& Ryan, R. M. (1985). Intrinsic motivation and self-determination in human behavior. Perspectives in social psychology. 
Matematik Tarihi Destekli Matematik Derslerine Yönelik Motivasyon Ölçeğinin Geliştirilmesi: Geçerlik ve Güvenirlik Çalışması

Deci, E. L., \& Ryan, R. M. (2000). The "what" and "why" of goal pursuits: human needs and the self-determination of behavior. Psychological Inquiry, 11, 227-268.

Deci, E. L., Spiegel, N. H., Ryan, R. M., Koestner, R., \& Kauffman, M. (1982). Effects of performance standards on teaching styles: Behavior of controlling teachers. Journal of educational psychology, 74(6), 852.

Deci, E. L., Vallerand, R. J., Pelletier, L. G., \& Ryan, R. M. (1991). Motivation and education: The self-determination perspective. Educational psychologist, 26(3-4), 325-346.

Dede, Y., \& Argün, Z. (2004). Öğrencilerin matematiğe yönelik içsel ve dışsal motivasyonlarının belirlenmesi. Eğitim ve Bilim, 29(134).

Dede, Y., \& Yaman, S. (2008). Fen öğrenmeye yönelik motivasyon ölçeği: Geçerlik ve güvenirlik çalışması. Necatibey Eğitim Fakültesi Elektronik Fen ve Matematik Eğitimi Dergisi, 2(1), 19-37.

Demir, M. K., \& Budak, H. (2016). İlkokul dördüncü sinif öğrencilerinin öz düzenleme, motivasyon, biliş üstü becerileri ile matematik dersi başarilarinin arasindaki ilişki. Dokuz. Eylül Üniversitesi Buca Ĕgitim Fakültesi Dergisi, (41), 30-41.

Deringöl, Y. (2018). Primary school students' mathematics motivation and anxieties. Cypriot Journal of Educational Sciences, 13(4), 537-548.

DeVellis, R. F. (2016). Scale development: Theory and applications (Vol. 26). Sage publications.

Dinçer, S., \& Doğanay, A. (2016). Öğretim materyali’ne İlişkin motivasyon ölçeği (ÖMMÖ) Türkçe uyarlama çalışması. İlköğretim Online, 15(4), 1131-1148.

Doğan, N., Soysal, S., \& Karaman, H. (2017). Aynı örnekleme açımlayıcı ve doğrulayıcı faktör analizi uygulanabilir mi?. Pegem Atı İndeksi, 373-400.

Drisscoll, M. P. (2012). Öğretim süreçleri ve öğrenme psikolojisi, (Çev.: Ö. F. Tutkun, S. Okay, E. Şahin) Ed. Ankara: Anı Yayıncılık.

Duda, J. L. \& Nicholls, J. G. (1992). Dimensions of achievement motivation in schoolwork and sport. Journal of educational psychology, 84(3), 290.

Elliot, A. J., \& Dweck, C. S. (Eds.). (2013). Handbook of competence and motivation. Guilford Publications.

Ergin, A., \& Karataş, H. (2018). Üniversite öğrencilerinin başarı odaklı motivasyon düzeyleri. Hacettepe Üniversitesi Eğitim Fakültesi Dergisi, 33(4), 868-887.

Ernest, P. (1998). Social constructivism as a philosophy of mathematics. Suny Press. 
Mersin \& Durmuş (2020)

Ersarı, G., \& Naktiyok, A. (2012). Iş görenin içsel ve dışsal motivasyonunda stresle mücadele tekniklerinin rolü/role of stress fighting tecniques in internal and external motivation of employees. Atatürk Üniversitesi Sosyal Bilimler Enstitüsü Dergisi, 16(1).

Ersoy, E., \& Oksuz, C. (2015). Primary school mathematics motivation scale. European Scientific Journal, 11(16).

Farmaki, V., \& Paschos, T. (2007). Employing genetic moments'in the history of mathematics in classroom activites. Educational Studies in Mathematics, 66, 83-106.

Fauvel, J. (1991). Using history in mathematics education. For the learning of mathematics, 11(2), 36.

Fauvel, J., Maanen, J. V., \& van Maanen, J. A. (2002). History in mathematics education: An ICMI study (Vol. 6).

Feldman, R. S. (2005). Understanding Psychology 7th E. New York: McGraw Hill Higher Education.

Fraenkel, J. R., Wallen, N. E., \& Hyun, H. H. (2012). How to design and evaluate research in education. New York: McGraw Hall.

Frias, C. M., \& Dixon, R. A. (2005). Confirmatory factor structure and measurement invariance of the Memory Compensation Questionnaire. Psychological Assessment, 17(2), 168.

Furinghetti, F. (2000). The history of mathematics as a coupling link between secondary and university teaching. International Journal of Mathematical Education in Science and Technology, 31(1), 43-51.

Glynn, S. M., Aultman, L. P., \& Owens, A. M. (2005). Motivation to learn in general education programs. The Journal of General Education, 54(2), 150-170.

Goktepe, S., \& Ozdemir, A. S. (2013). An example of using history of mathematics in classes. European Journal of Science and Mathematics Education, 1(3), 125-136.

Harrington, D. (2009). Confirmatory factor analysis. Oxford university press

Haverhals, N. \& Roscoe, M. (2010). The history of mathematics as a pedagogical tool: teaching the integral of the secant via Mercator's projection. The Montana Mathematics Enthusiast, 7(2-3), 339-360.

Hodges, C. B. (2004). Designing to motivate: motivational techniques to incorporate in elearning experiences, The Journal of Interactive Online Learning, 2(3),1-7. 
Matematik Tarihi Destekli Matematik Derslerine Yönelik Motivasyon Ölçeğinin Geliştirilmesi: Geçerlik ve Güvenirlik Çalışması

Hu, L. \& Bentler, P. (2000). Cutoff criteria for fit indexes in covariance structure analysis: Conventional criteria versus new alternatives. Structural Equation Modeling, 6(1), 1-55.

Hussien, J. H. (2011). The self-determination theory and mathematics motivation: grade levels and gender differences among united arab emirates students. Journal of Educational and Psychological Studies [JEPS], 5(1), 15-31.

İspir, O. A., Ay, Z. S., \& Sayg1, E. (2011). Üstün başarılı öğrencilerin özdüzenleyici öğrenme stratejileri, matematiğe karşı motivasyonları ve düşünme sitilleri. Eğitim ve Bilim, 36(162).

Jankvist, U. T. (2009). A categorization of the - whys and - hows of using history in mathematics education. Educational studies in Mathematics, 71(3), 235-261.

Jöreskog, K. G. \& Sörbom, D. (1993). LISREL 8: Structural equation modeling with the SIMPLIS command language. Scientific Software International.

Kara, A. (2008). İlköğretim Birinci Kademede Eğitimde Motivasyon Ölçeğinin Türkçeye Uyarlanması. Ege Ë̆itim Dergisi, 9(2), 59-78.

Kass, R., \& Tinsley, H. E. (1998). E. (1979). Factor analysis. Journal of Leisure Research, 11, 120-138.

Kesici, A. (2018). Lise Öğrencilerinin Matematik Motivasyonunun Matematik Başarısına Etkisinin İncelenmesi. Ondokuz Mayis University Journal of Education, 37(2).

Kılıç, Y., \& Yılmaz, E. (2019). İçsel, dışsal ve yönetsel faktörler bağlamında öğretmen motivasyon ölçeği’nin geliştirilmesi. Eğitim Kuram ve Uygulama Araştırmaları Dergisi, 5(1), 77-91.

Kline, R. B. (1998). Principles and practice of structural equation modeling. 1998. New York: Guilford.

Köyceğiz, M., \& Özbey, S. (2019). Okul öncesi eğitim kurumlarına devam eden çocukların motivasyon düzeylerinin problem çözme becerileri ve öğretmenlerine ilişkin bazı değişkenler açısından incelenmesi. Folklor/Edebiyat, 25(97), 554-574.

Kurnaz, H. (2019). Okuma iç motivasyonu ölçeği: geçerlik ve güvenirlik çalışması. Kırşehir Ĕ̈itim Fakültesi Dergisi, 20(1), 234-250.

Lazowski, R. A., \& Hulleman, C. S. (2016). Motivation interventions in education: A meta-analytic review. Review of Educational research, 86(2), 602-640.

Lim, S. Y., \& Chapman, E. (2015). Adapting the academic motivation scale for use in pre-tertiary mathematics classrooms. Mathematics Education Research Journal, 27(3), 331-357. 
Mersin \& Durmuş (2020)

Lim, S. Y., \& Chapman, E. (2015). Effects of using history as a tool to teach mathematics on students' attitudes, anxiety, motivation and achievement in grade 11 classrooms. Educational Studies in Mathematics, 90(2), 189-212.

Linder, S. M., Smart, J. B., \& Cribbs, J. (2015). A multi-method investigation of mathematics motivation for elementary age students. School Science and Mathematics, 115(8), 392-403.

Liu, P. H. (2003). Do teachers need to incorporate the history of mathematics in their teaching. Mathematics Teacher, 96(6), 416-421.

Mac an Bhaird, Ciaran (2009) Introducing the history of mathematics to third level students with weak mathematical backgrounds: a case study. In: CETL-MSOR Conference 2008. The Maths, Stats \& OR Network, pp. 63-68. ISBN 978-0-9555914-5-7

Marcoulides, G. \& Schumacher, R. (2001). New developments and techniques in structural equation modelling. London: Lawrence Erlbaum Associates Publishers.

Marsh, H.W., Balla, JR., \& McDonald, R.P., (1988). Goodness-of-fit indexes in confirmatory factory analysis: the effects of sample size. Psychological Bulletin, 103(3), 391-410.

Marshall, G. L., \& Rich, B. S. (2000). The role of history in a mathematics class. The Mathematics Teacher, 93(8), 704-706.

Marshall, G. L., (2000). Using history of mathematics to improve secondary students' attitudes towards mathematics, Ph.D. Thesis, Illinois State University.

Martin, A. J. (2001). The student motivation scale: A tool for measuring and enhancing motivation. Australian Journal of Guidance and Counselling, 11, 11-20.

McKenzie, K., \& Schweitzer, R. (2001). Who succeeds at university? Factors predicting academic performance in first year Australian university students. Higher education research \& development, 20(1), 21-33.

MEB. (2013). Okul Öncesi Eğitim Programı. ttkb.meb.gov.tr adresinden 10 Mayıs 2020 tarihinden erişilmiştir.

Middleton, J. A. \& Spanias, P. A. (1999). Motivation for achievement in mathematics: Findings, generalizations, and criticisms of the research. Journal for research in Mathematics Education, 30, 65-88.

Moddleton, J.A. (2014). Motivation in Mathematics Learning. In S. Lerman (Ed). Encyclopedia of Mathematics Education (pp. 460- 463). Dordrecht, Netherland: Springer. 
Matematik Tarihi Destekli Matematik Derslerine Yönelik Motivasyon Ölçeğinin Geliştirilmesi: Geçerlik ve Güvenirlik Çalışması

Müezzin, E. E., \& Özata, B. Ç. (2019). Ortaöğretim öğrencilerinde fen öğrenmeye yönelik kayg1 ve motivasyon ilişkisi. Kıbrıs Türk Psikiyatri ve Psikoloji Dergisi, 1(1), 14-21.

Nataraj, M. S., \& Thomas, M. O. (2009). Developing understanding of number system structure from the history of mathematics. Mathematics Education Research Journal, 21(2), 96-115.

Oie, M., \& Fujie, Y. (2007). Motivation on science and mathematics across elementary school to junior high school: making measurement of motivation on mathematics. Bulletin of the Research Center for Child \& Adolescent Development \& Education Ochanomizu University, 4, 75-81.

Öksüz, C. (2015). Examining primary school students'levels of mathematics motivation. European Scientific Journal, 11(28).

Orosco, M. J. (2016). Measuring elementary student's mathematics motivation: a validity study. International Journal of Science and Mathematics Education, 14(5), 945-958.

Özgen, K., \& Bayram, B. (2019). Problem kurma öz yeterlik ölçeğinin geliştirilmesi. Ilkogretim Online, 18(2).

Panasuk, R. M., \& Horton, L. B. (2012). Integrating history of mathematics into curriculum: what are the chances and constraints?. International Electronic Journal of Mathematics Education, 7(1), 3-20.

Panasuk, R. M., \& Horton, L. B. (2013). Integrating history of mathematics into the classroom: was aristotle wrong?. Journal of Curriculum and Teaching, 2(2), 37-46.

Pett, M. A., Lackey, N. R., \& Sullivan, J. J. (2003). Making sense of factor analysis. USA: Sage Publication.

Philippou, G. N., \& Christou, C. (1998). Beliefs, teacher education and the history of mathematics. In PME Conference (Vol. 4, pp. 4-1).

Pintrich P.R., \& Schunk D.H. (2002). Motivation in education: Theory, research, and applications (2nd ed.). New Jersey: Prentice Hall.

Pintrich, P., \& Schunk, D. (1996). The role of expectancy and self-efficacy beliefs. Motivation in education: Theory, research \& applications, 3.

Plenty, S., \& Heubeck, B. G. (2013). A multidimensional analysis of changes in mathematics motivation and engagement during high school. Educational Psychology, 33(1), 14-30.

Ponza, M. V. (1998). A Role for the History of Mathematics in the Teaching and Learning of Mathematics: An Argentinian Experience. Mathematics in school, 27(4), 10-13. 
Mersin \& Durmuş (2020)

Reimer, L., \& Reimer, W. (1995). Connecting mathematics with its history: A powerful, practical linkage. Connecting mathematics across the curriculum, 104-114.

Rickey, F. (1995). My favorite ways of using history in teaching calculus. Learn from the masters, 123-134.

Ryan, R. M., \& Deci, E. L. (2000). Intrinsic and extrinsic motivations: Classic definitions and new directions. Contemporary Educational Psychology, 25, 54-67.

Scherer, R. F., Luther, D. C., Wiebe, F. A., \& Adams, J. S. (1988). Dimensionality of coping: Factor stability using the ways of coping questionnaire. Psychological Reports, 62(3), 763 770 .

Schermelleh-Engel, K., Moosbrugger, H. \& Müller, H. (2003). Evaluating the fit of structural equation models: Tests of significance and descriptive goodness-of-fit measures. Methods of psychological research online, 8(2), 23-74.

Schumaker, R., \& Lomax, R. (2004). A beginner's guide to structural equation modeling ( $2^{\text {nd }}$ ed.). Mahwah, NJ: Psychology Press.

Schunk, D.H. (2009). Öğrenme teorileri: Eğitimsel bir bakışla. (M. Şahin, çev. ed.). Ankara: Nobel Yayınlar1.

Şen, M., Demir, E., Teke, N.\& Yılmaz, A. (2020). Erken çocukluk ebeveyn medya aracılık ölçeği geliştirme çalışması. Mehmet Akif Ersoy Üniversitesi Eğitim Fakültesi Dergisi, (53), 228265.

Sertöz, S. (1999). Matematiğin aydınlık dünyası (9. Basım). TÜBİTAK Popüler Bilim Kitaplarl36. İstanbul: Pro-Mat Basım Yayın AŞ.

Şimşek, Ö.F. (2007). Yapısal Eşitlik Modellemesine Giriş: Temel İlkeler ve Lisrel Uygulamalari. Ekinoks, Ankara.

Stipek, D. J. (1996). Motivation and instruction. Handbook of educational psychology, 1, 85-113.

Stipek, D., Givvin, K. B., Salmon, J. M., \& MacGyvers, V. L. (1998). Can a teacher intervention improve classroom practices and student motivation in mathematics?. The Journal of Experimental Education, 66(4), 319-337.

Sümer, N. (2000). Yapısal eşitlik modelleri: temel kavramlar ve örnek uygulamalar. Türk Psikoloji Yazllarl, 3(6):74-79.

Süren, N. (2019). Kaygı ve motivasyonun matematik başarısına etkisinin incelenmesi. Yüksek lisans tezi, Balıkesir Üniversitesi, Fen Bilimleri Enstitüsü, Balıkesir. 
Matematik Tarihi Destekli Matematik Derslerine Yönelik Motivasyon Ölçeğinin Geliştirilmesi: Geçerlik ve Güvenirlik Çalışması

Tabachnick, B.G. \& Fidell, L.S. (2007). Using multivariate statistics (5th ed.). Pearson Education, Inc. / Allyn and Bacon.

Tahiroğlu, M., \& Çakır, S. (2014). İlkokul 4. sınıflara yönelik matematik motivasyon ölçeğinin geliştirilmesi. Journal of Kirsehir Education Faculty, 15(3).

Tanaka, J. S. \& Huba, G. J. (1985). A fit index for covariance structure models under arbitrary GLS estimation. British Journal of Mathematical and Statistical Psychology, 38(2), 197-201.

Tzanakis, C., Arcavi, A., de Sa, C. C., Isoda, M., Lit, C. K., Niss, M., ... \& Siu, M. K. (2002). Integrating history of mathematics in the classroom: an analytic survey. In History in mathematics education (pp. 201-240). Springer, Dordrecht.

Üredi, I., \& Üredi, L. (2005). İlköğretim 8. sınıf öğrencilerinin öz-düzenleme stratejileri ve motivasyonel inançlarının matematik başarısını yordama gücü. Mersin Üniversitesi Eğitim Fakültesi Dergisi, 1(2), 250-260.

Utvær, B. K. S., \& Haugan, G. (2016). The academic motivation scale: dimensionality, reliability, and construct validity among vocational students. Nordic Journal of Vocational Education and Training, 6(2), 17-45.

Vallerand, R. J., Pelletier, L. G., Blais, M. R., Briere, N. M., Senecal, C., \& Vallieres, E. F. (1992). The academic motivation scale: a measure of intrinsic, extrinsic, and amotivation in education. Educational and psychological measurement, 52(4), 1003-1017.

Viau, R. (2009). La motivation à apprendre en milieu scolaire. Saint-Laurent: ERPI.

Worthington, R. L., \& Whittaker, T. A. (2006). Scale development research: A content analysis and recommendations for best practices. The counseling psychologist, 34(6), 806-838.

Yılmaz, V. \& Çelik, H. E. (2009). Lisrel ile yapısal eşitlik modellemesi-1. Ankara: Pegem Yayınc1lik.

Yunus, A. S. \& Ali, W. Z. W. (2008). "Metacognition and motivation in problem solving", International Journal of Learning, 15(3), 121-132. 